\title{
Anti-Inflammatory Effects of Licania macrocarpa Cuatrec Methanol Extract Target Src- and TAK1-Mediated Pathways
}

\author{
Kon Kuk Shin $\mathbb{D}^{1},{ }^{1}$ Jae Gwang Park $\left(\mathbb{D},{ }^{1,2}\right.$ Yo Han Hong, ${ }^{1}$ Nur Aziz $\mathbb{D}^{1},{ }^{1}$ Sang Hee Park $\mathbb{D}^{3},{ }^{3}$ \\ Sunggyu Kim $\left(\mathbb{0},{ }^{3,4}\right.$ Eunji Kim $\mathbb{1 0},{ }^{1}$ and Jae Youl Cho $\mathbb{1}^{1,3}$ \\ ${ }^{1}$ Department of Integrative Biotechnology, Sungkyunkwan University, Suwon 16419, Republic of Korea \\ ${ }^{2}$ Division of Translational Science, Research Institute, National Cancer Center, Goyang 10408, Republic of Korea \\ ${ }^{3}$ Department of Biocosmetics, Sungkyunkwan University, Suwon 16419, Republic of Korea \\ ${ }^{4}$ Research and Business Foundation, Sungkyunkwan University, Suwon 16419, Republic of Korea
}

Correspondence should be addressed to Sunggyu Kim; sukim590@skku.edu; Eunji Kim; im144069@gmail.com; and Jae Youl Cho; jaecho@skku.edu

Received 23 June 2019; Revised 13 August 2019; Accepted 17 August 2019; Published 12 September 2019

Academic Editor: Hajime Nakae

Copyright ( 92019 Kon Kuk Shin et al. This is an open access article distributed under the Creative Commons Attribution License, which permits unrestricted use, distribution, and reproduction in any medium, provided the original work is properly cited.

\begin{abstract}
In this study, we investigated the anti-inflammatory effects of Licania macrocarpa Cuatrec methanol extract (Lm-ME) in vitro and in vivo and found pharmacological target proteins of Lm-ME in TLR4-mediated inflammatory signaling. This extract reduced NO production and mRNA expression of inflammatory cytokines such as iNOS, COX-2, IL-6, and IL- $1 \beta$. In the NF- $\kappa \mathrm{B}-$ and AP-1mediated luciferase reporter gene assay, transcription factor activities decreased under cotransfection with MyD88 or TRIF. Phosphorylated protein levels of Src, PI3K, IKK $\alpha / \beta$, and $\mathrm{I} \kappa \mathrm{B} \alpha$ as well as p50 and p 65 in the NF- $\kappa \mathrm{B}$ signal pathway were downregulated, and phosphorylation of TAK1, MEK1/2, MKK4/7, and MKK3/6 as well as ERK, JNK, and p38 was decreased in the AP-1 signal pathway. Through overexpression of HA-Src and HA-TAK1, respectively, Lm-ME inhibited autophosphorylation of overexpressed proteins and thereby activated fewer downstream signaling molecules. Lm-ME also attenuated stomach ulcers in an $\mathrm{HCl} / \mathrm{EtOH}$-induced acute gastritis model mice, and COX-2 mRNA expression and phosphorylated TAK1 levels in gastric tissues were diminished. The flavonoids kaempferol and quercetin were identified in the HPLC analysis of Lm-ME; both are actively anti-inflammatory. Therefore, these results suggest that Lm-ME can be used for anti-inflammatory remedy by targeting Src and TAK1.
\end{abstract}

\section{Introduction}

Inflammation is the first defense against many infectious pathogens or injury, and it plays an important role in common causes of atherosclerotic cardiovascular disease, cancer, and chronic obstructive lung disease [1-3]. In particular, toll-like receptors (TLRs) are key factors of the innate immune system that also recognize pathogen-associated molecular patterns (PAMPs), which are molecular motifs shared by different types of microbes $[4,5]$. TLRs are expressed on dendritic cells, macrophages, natural killer cells, T cells, B cells, epithelial cells, endothelial cells, and fibroblasts [6]. Four particular adapter molecules of TLRs are known to be involved in signaling: MyD88, TIRAP, TRIF, and TRAM [7].
TLR4 recognizes microbial components, including lipopolysaccharides (LPS) and saturated fatty acids (SFA) [8], and can induce signaling through MyD88 and TRIF [9]. In the case of TLR4 activation, there are two different ways to activate inflammation: a MyD88-dependent pathway and a MyD88-independent pathway. In the case of the MyD88dependent pathway, MyD88 recruits IRAK4 to activate and degrade IRAK1. IRAK1 is associated with TRAF6, and the complex can activate TAK1, which activates the $\mathrm{I} \kappa \mathrm{B}$ kinase (IKK) and mitogen-activated protein kinase (MAPK). This IKK-related complex can activate NF- $\kappa \mathrm{B}$, and the MAPKrelated protein activates the AP-1 pathway $[8,10]$. In the MyD88-independent pathway, however, TRIF takes part in late-phase NF- $\kappa \mathrm{B}$ and MAPK signaling, because TRIF recruits TRAF6 and receptor-interacting protein 1 (RIP1) to 
activate TAK1, resulting in NF- $\kappa \mathrm{B}$ activation. Additional TLR4 downstream signaling molecules PI3K and AKT also activate the NF- $\kappa$ B pathway [11-13].

NF- $\kappa \mathrm{B}$ and AP-1 transcription factors can induce inflammatory cytokines such as TNF- $\alpha$, IL- $1 \beta$, IL- 6 , iNOS, and COX-2 $[14,15]$. These cytokines can induce pathological pain and promote inflammation [16]. Nitric oxide (NO), in particular, is produced by inducible nitric oxide synthase (iNOS) and plays roles in blood pressure regulation, inflammation, infection, and the onset of progression of malignant disease [17]. Poor regulation of these inflammation symptoms can lead to many diseases, including cardiovascular disease, cancer, rheumatoid arthritis, allergy, asthma, and Alzheimer's and chronic kidney disease [18]. Accordingly, many researchers have focused on inflammatory signaling targets and also identified candidate substances that prevent inflammatory cytokine production and inflammation-related protein or gene expression.

Licania macrocarpa Cuatrec belongs to the genus Licania (chrysobalanaceae), which consists of more than 200 species distributed mainly in the Americas, especially from Panama to Peru [19]. Licania species have been used as medicinal plants in South America to treat inflammation, diabetes, stomach ailments, diarrhea, and dysentery [20]. Despite traditional use, the medicinal mechanisms of the genus Licania have not been well characterized at the cellular and molecular levels. Therefore, we focused on the anti-inflammatory effects of a methanol extract of $L$. macrocarpa Cuatrec (Lm-ME) both in vitro, by using macrophage-like RAW264.7 cells, and in vivo, by using an $\mathrm{HCl} / \mathrm{EtOH}$-induced acute gastritis mouse model. To check for anti-inflammatory effects, we conducted an NO assay in macrophage-like RAW264.7 cells and peritoneal macrophages and also examined inflammation-related mRNA expression of cytokines such as IL-6, IL- $1 \beta$, iNOS, and COX2 . To find target proteins that are affected by Lm-ME in the TLR4 pathway, we utilized a luciferase reporter gene assay, western blotting, and an overexpression strategy. To identify the active components of Lm-ME, we carried out HPLC analysis using flavonoids related to anti-inflammatory effects.

\section{Materials and Methods}

2.1. Materials. Methanol extract of L. macrocarpa Cuatrec (Lm-ME; code no: PBEC10204) was purchased from the Plant Extract Bank of the Plant Diversity Research Centre (Daejeon, Korea). RAW264.7 cells (a BALB/c-derived murine macrophage cell line (ATCC No. TIB-71)) and HEK293T cells (a human embryonic kidney cell line (ATCC No. CRL-1573)) were purchased from ATCC (Rockville, MD, USA). Cell culture reagents such as media (RPMI 1640 and DMEM) and FBS were purchased from Hyclone (Grand Island, NY, USA) and Biotechnics Research (Lake Forest, CA, USA). Dimethylsulfoxide (DMSO), 3(4,5-Dimethylthiazol-2-yl)-2,5-diphenyltetrazolium bromide (MTT), lipopolysaccharide (LPS, Escherichia coli 0111:B4), $\mathrm{N}^{\omega}$-nitro-L-arginine methyl ester hydrochloride
(L-NAME), quercetin, kaempferol, luteolin, carboxymethylcellulose (CMC), PP2, and 5Z-7-Oxozeaenol were purchased from Sigma Chemical Co. (St. Louis, MO, USA). Luciferase constructs containing NF- $\kappa \mathrm{B}$ - or AP-1-binding promoters were acquired from Promega (Madison, WI, USA). Epitope-tagged constructs (FLAG-MyD88, CFPTRIF, HA-Src, and HA-TAK1) were obtained from Addgene (Cambridge, MA, USA). Phospho-specific and total antibodies against p50 (Catalog number: \#4806, $\# 3035), \mathrm{p} 65$ (\#3033, \#8242), I $\kappa \mathrm{B} \alpha(\# 5209, \# 4812), \mathrm{IKK} \alpha / \beta$ (\#2697, \#2682), Src (\#2101, \#2109), p85 (\#4228, \#4292), ERK (\#9101, \#4696), JNK (\#9255, \#4672), p38 (\#4631, \#9212), MEK1/2 (\#9121, \#9122), MKK4 (\#9151, \#9152), MKK3/6 (\#9236, \#9238), MKK7 (\#4171, \#4172), TAK1 (\#9339, \#4505), IRAK1 (\#4504), IRAK4 (\#4363), FLAG (\#8146), TRIF (\#4596), HA (\#5017) and loading control proteins (lamin A/C (\#4777), and $\beta$-actin (\#4967)) were purchased from Cell Signaling (Beverly, MA, USA).

2.2. Cell Culture. RAW264.7 cells were cultured in RPMI 1640 with $10 \%$ heat-inactivated FBS and antibiotics (penicillin and streptomycin). HEK293T cells were cultured in DMEM with 5\% heat-inactivated FBS and antibiotics (penicillin and streptomycin). All cells were incubated at $37^{\circ} \mathrm{C}$ under $5 \% \mathrm{CO}_{2}$.

2.3. Lm-ME Treatment and Administration. A stock of LmME $(25.93 \mathrm{~g})$ was dissolved in $100 \%$ DMSO $(1.10 \mathrm{~g} / \mathrm{ml})$ to make $100 \mathrm{mg} / \mathrm{ml}$ of Lm-ME for in vitro experiments. LmME was further diluted to $50-200 \mu \mathrm{g} / \mathrm{ml}$ for treatment with medium. For in vivo experiments, the stock of Lm-ME was suspended in $0.5 \%$ CMC at a concentration of $100 \mathrm{mg} / \mathrm{kg}$ and $200 \mathrm{mg} / \mathrm{kg}$.

2.4. NO Production. Macrophage-like RAW264.7 $\left(1 \times 10^{6}\right.$ cells $/ \mathrm{ml}$ ) cells were precultured for $18 \mathrm{~h}$ and then pretreated with $\mathrm{Lm}-\mathrm{ME}(0,50,100$, and $200 \mu \mathrm{g} / \mathrm{ml})$ for $30 \mathrm{~min}$, followed by LPS $(1 \mu \mathrm{g} / \mathrm{ml})$ treatment for $24 \mathrm{~h}$. In some cases, L-NAME $(0.5,1$, and $2 \mathrm{mM}), \mathrm{PP} 2(10,20$, and $40 \mu \mathrm{M})$, and $5 \mathrm{Z}-7-$ oxozeaenol $(0.625,1.25$, and $2.5 \mu \mathrm{M})$ were used for pretreatment instead of Lm-ME. To measure NO production, $100 \mu \mathrm{l}$ of supernatant of cell culture media and $100 \mu \mathrm{l}$ of Griess reagent were mixed for $1 \mathrm{~min}$, and absorbance was measured at $540 \mathrm{~nm}$ using a spectrophotometer.

2.5. Cell Viability Test. The cytotoxic effects of Lm-ME in RAW264.7, HEK293T, and peritoneal macrophage cells were determined by conventional MTT assay as previously described [21].

2.6. High-Performance Liquid Chromatography (HPLC). To identify the active components of Lm-ME, high-performance liquid chromatography (HPLC) was conducted as reported previously [22]. Standard compounds quercetin, kaempferol, and luteolin were used. 
2.7. Semiquantitative Reverse Transcriptase-Polymerase Chain Reaction (RT-PCR). RAW264.7 cells were pretreated with $0,50,100$, or $200 \mu \mathrm{g} / \mathrm{ml}$ of Lm-ME for $30 \mathrm{~min}$ and then incubated for $6 \mathrm{~h}$ with $1 \mu \mathrm{g} / \mathrm{ml}$ of LPS. Semiquantitative RTPCR was conducted as described previously [23]. The primer sequences are listed in Table 1.

2.8. Luciferase Reporter Gene Assay and Transfection. For the luciferase assay, HEK293T cells $\left(1.25 \times 10^{5}\right.$ cells/well $)$ were plated in 24-well plates for $18 \mathrm{~h}$. Luciferase genes $(\mathrm{NF}-\kappa \mathrm{B}$ or AP-1), signaling construct (MyD88 or TRIF) and the $\beta$-galactosidase gene (as a control) were mixed together in Opti-MEM media for $15 \mathrm{~min}$, and the transfection reagent, PEI, was diluted with Opti-MEM for $15 \mathrm{~min}$. After stabilization of the genes and PEI, both were mixed together for $20 \mathrm{~min}$. The mixture was then added to HEK293T cells for $24 \mathrm{~h}$. For transfection of Src and TAK1, HEK293T cells $\left(2.5 \times 10^{5}\right.$ cells $\left./ \mathrm{ml}\right)$ were plated in 6 wells for $18 \mathrm{~h}$. The HASrc or HA-TAK1 genes were diluted in Opti-MEM, and PEI was also diluted in Opti-MEM, each for $15 \mathrm{~min}$. After stabilization of the genes and PEI, they were mixed together for $20 \mathrm{~min}$. The mixture was added to HEK293T cells for $24 \mathrm{~h}$.

2.9. Western Blotting Analysis. Nuclear fraction lysate and total lysates of Lm-ME-treated RAW264.7 $\left(1 \times 10^{6}\right.$ cells/ml $)$ and HEK293T $\left(2.5 \times 10^{5}\right.$ cells $\left./ \mathrm{ml}\right)$ cells were extracted with lysis buffer as described previously [24]. Tissue lysates of $\mathrm{HCl} / \mathrm{EtOH}$-induced mouse stomachs were also prepared. Immunoblotting analysis was performed as previously reported [25]. The antibodies against total and phosphorylated forms of IKK $\alpha / \beta$ (\#2697, \#2682), I $\kappa \mathrm{B} \alpha$ (\#5209, \#4812), p50 (\#4806, \#3035), p65 (\#3033, \#8242), Src (\#2101, \#2109), p85 (\#4228, \#4292), ERK (\#9101, \#4696), JNK (\#9255, \#4672), p38 (\#4631, \#9212), MEK1/2 (\#9121, \#9122), MKK4 (\#9151, \#9152), MKK3/6 (\#9236, \#9238), MKK7 (\#4171, \#4172), TAK1 (\#9339, \#4505), IRAK1 (\#4504), IRAK4 (\#4363), $\beta$-actin (\#4967), FLAG (\#8146), TRIF (\#4596), and HA (\#5017) were evaluated.

2.10. Preparation of Peritoneal Macrophages. Peritoneal macrophages were collected from peritoneal exudates of ICR mice that were injected intraperitoneally with $4 \%$ thioglycollate broth ( $1 \mathrm{ml}$, Difco Laboratories, Detroit, MI, USA). After 4 days, the mice were anesthetized with isoflurane and sacrificed. Five $\mathrm{ml}$ of PBS was injected into the belly and massaged. After enough massage, PBS was collected into a $50 \mathrm{ml}$ tube 4 times. Cells were pelleted by centrifugation $\left(3,000 \mathrm{rpm}, 5 \mathrm{~min}, 4^{\circ} \mathrm{C}\right)$. After discarding the supernatant, the pelleted cells were resuspended and washed with $10 \mathrm{ml}$ of RBC buffer and centrifuged. After lysis of the red blood cells, the remaining cells were resuspended with RPMI media and plated into 96 wells.

2.11. HCl/EtOH-Induced Gastritis Mice. Acute gastritis was induced with $300 \mu \mathrm{l}$ of $150 \mathrm{mM} \mathrm{HCl}$ in $60 \% \mathrm{EtOH}$ as previously reported in ICR mice [14]. We orally injected 0,100 , or $200 \mathrm{mg} / \mathrm{kg}$ of Lm-ME for the gastritis-induced groups and
TABLE 1: Sequences of primers used in RT-PCR analysis.

\begin{tabular}{lc}
\hline Gene & Sequences $\left(5^{\prime} \longrightarrow 3^{\prime}\right)$ \\
\hline iNOS & \\
Forward & $5^{\prime}$-CCCTTCCGAAGTTTCTGGCAGCAGC-3' \\
Reverse & $5^{\prime}$-GGCTGTCAGAGCCTCGTGGCTTTGG-3' \\
COX-2 & \\
Forward & $5^{\prime}$-CACTACATCCTGACCCACTT-3' \\
Reverse & $5^{\prime}$-ATGCTCCTGCTTGAGTATGT-3' \\
IL-6 & \\
Forward & $5^{\prime}$-GTACTCCAGAAGACCAGAGG-3' \\
Reverse & $5^{\prime}$-TGCTGGTGACAACCACGGCC-3' \\
IL-1 $\beta$ & \\
Forward & $5^{\prime}$-CAGGATGAGGACATGAGCACC-3' \\
Reverse & $5^{\prime}$-CTCTGCAGACTCAAACTCCAC-3' \\
GAPDH & \\
Forward & $5^{\prime}$-CACTCACGGCAAATTCAACGGCAC-3' \\
Reverse & $5^{\prime}$-GACTCCACGACATACTCAGCAC-3' \\
\hline
\end{tabular}

$40 \mathrm{mg} / \mathrm{kg}$ of ranitidine for the control group 3 times in ICR mice. Eight hour after the last oral injection, $300 \mu \mathrm{l}$ of $150 \mathrm{mM} \mathrm{HCl} / 60 \% \mathrm{EtOH}$ was orally administrated for $1 \mathrm{~h}$ and ICR mice were anesthetized with isoflurane and sacrificed. The stomachs were excised, rinsed with PBS, and cut along the greater curvature. The area of mucosal erosive lesions was measured by Image J and counting the pixels of lesions.

2.12. Real-Time Polymerase Chain Reaction (Real-Time PCR). The mRNA expression level of gastritis stomach sample was quantified in gastritis stomach samples. mRNA was isolated with TRIzol Reagent (Gibco) according to the manufacturer's manual. mRNA levels were quantified by real-time reverse transcription-polymerase chain reaction using SYBR premix Ex Taq (PCR Biosystems, London, UK). The realtime mRNA expression results were calculated relative to the housekeeping gene GAPDH. The primer sequences are listed in Table 2.

2.13. Statistical Analyses. All data presented in this study are expressed as means \pm standard deviation (SD) from three independent experiments. For statistical comparisons, ANOVA/Scheffe's post hoc test or the Kruskal-Wallis/ Mann-Whitney tests were employed. $P$ values $<0.05$ were considered statistically significant.

\section{Results}

3.1. Lm-ME Reduced Nitric Oxide (NO) Production. To figure out the inflammatory effects of Lm-ME, we first checked the inhibitory effect on NO production in LPS-induced RAW264.7 cells and peritoneal macrophages (Figure 1(a)). We used L-NAME as a positive control, because L-NAME exhibits selectivity for inhibition of NOS [26], and we say that it decreased NO production (Figure 1(b)). Importantly, Lm-ME $(50-200 \mu \mathrm{g} / \mathrm{ml})$ did not show any cytotoxicity in RAW264.7 cells, HEK293T cells, or peritoneal macrophages by MTT assay (Figure 1(c)), so NO decreases were not due to cell death. Next, to verify the components of Lm-ME that 
TABLE 2: Sequences of primers used in real-time analysis.

\begin{tabular}{lc}
\hline Gene & Sequences $\left(5^{\prime} \longrightarrow 3^{\prime}\right)$ \\
\hline COX-2 & \\
Forward & $5^{\prime}$-AAGGTGAGAAGCAATGCAGC-3' \\
Reverse & $5^{\prime}$-CCACTCAGGGAGTTCTCTCT-3' \\
GAPDH & \\
Forward & $5^{\prime}$-CAATGAATACGGCTACAGCAAC-3' \\
Reverse & $5^{\prime}$-AGGGAGATGCTCAGTGTTGG-3' \\
\hline
\end{tabular}

might be responsible for anti-inflammatory effects, we performed HPLC analysis using flavonoids, including quercetin, kaempferol, and luteolin, because they are known to have anti-inflammatory effects [27]. Lm-ME contained $2.287 \mathrm{mg} / \mathrm{g}$ of quercetin and $0.477 \mathrm{mg} / \mathrm{g}$ of kaempferol (Figure 1(d)), implying that these flavonoids (quercetin and kaempferol) in Lm-ME suppressed LPS-induced NO production.

\subsection{Anti-Inflammatory Effects of Lm-ME on Transcriptional} Level. Treatment of RAW264.7 cells with LPS can induce mRNA expression of proinflammatory molecules [28]. Accordingly, we investigated mRNA expression levels of proinflammatory genes. iNOS, COX-2, and IL-6 were strongly inhibited by 100 and $200 \mu \mathrm{g} / \mathrm{ml} \mathrm{Lm-ME}$, and IL- $1 \beta$ was also slightly inhibited by Lm-ME (Figure 2(a)). In addition, we checked the transcriptional inhibitory effect of Lm-ME using a luciferase reporter gene assay. We transfected MyD88 or TRIF, which are key molecules in TLR4 signals, into macrophages with NF- $\kappa \mathrm{B}$ and AP-1 luciferase promoter genes [29]. Transfection of adaptor molecules (MyD88 and TRIF) in HEK293T cells mimicked the activation of RAW264.7 cells with LPS [30]. NF- $\kappa$ B luciferase activity was decreased by Lm-ME in a dose-dependent manner in both MyD88 and TRIF-transfected conditions (Figure 2(b)). Moreover, AP-1 luciferase activity was decreased by Lm-ME in MyD88 and TRIF-transfected conditions (Figure 2(c)). Based on the luciferase assay results, we next explored whether Lm-ME downregulated nuclear translocation levels of c-Jun and c-Fos. At 30 and $60 \mathrm{~min}$, the Lm-ME-treated group had lower c-Jun and c-Fos protein levels in the nucleus (Figure 2(d)). The protein levels of MyD88 (by FLAG) and TRIF in luciferase assay looked to be similar between all groups (Figures 2(b)-2(e)). In conclusion, based on luciferase activity and nuclear c-Jun and c-Fos results, Lm-ME can alleviate the LPS-induced signaling pathway.

3.3. Regulatory Mechanism of Lm-ME in NF- $\kappa B$ and AP-1 Pathways. Since proinflammatory cytokines (e.g., IL-6 and IL-1 $\beta$ ) are related to the NF- $\kappa$ B pathway, we expected Lm$\mathrm{ME}$ to attenuate signal proteins passing through the NF- $\kappa \mathrm{B}$ pathway. To explore the effect of Lm-ME on NF- $\kappa$ B signaling, we treated cells with Lm-ME at a concentration of $200 \mu \mathrm{g} / \mathrm{ml}$, because $200 \mu \mathrm{g} / \mathrm{ml}$ of Lm-ME showed the highest NO inhibition without cytotoxicity (Figures 1(a) and 1(b)). When we checked western blotting in a time-dependent manner, the protein levels of phosphorylation of NF- $\kappa \mathrm{B}$ transcription subunits p50 and p65 were downregulated starting 5 and $15 \mathrm{~min}$ after treatment with $200 \mu \mathrm{g} / \mathrm{ml} \mathrm{Lm-}$ $\mathrm{ME}$, and phospho-I $\kappa \mathrm{B} \alpha$ clearly decreased starting after $5 \mathrm{~min}$ (Figure 3(a)). In LPS induction, activation of $\mathrm{c}-\mathrm{Src}$ and ubiquitous Src tyrosine kinase is required for the NF- $\kappa$ B pathway activation in macrophages [31]. To check responses over a short time period, we conducted western blotting after 3 and 5 min in LPS-treated RAW264.7 cells to determine the amount of phosphorylation of protein tyrosine kinase ( $\mathrm{Src}$ ) and phosphoinositide 3-kinases (p85). Both were suppressed by Lm-ME starting at $3 \mathrm{~min}$ (Figure 3(b)), implying that Src is a target protein of Lm-ME.

Previous data from the luciferase assay and nuclear fraction showed that Lm-ME can also attenuate the AP-1 pathway (Figures 2(c) and 2(d)). To find target molecules in AP-1 signaling, we conducted western blotting analysis to examine mitogen-activated protein kinases (MAPKs) including extracellular signal-regulated kinases (ERKs), c-Jun $\mathrm{N}$-terminal kinases (JNKs), and p38. ERK was inhibited at all times (0-60 min), and JNK and p38 phosphorylation was decreased by Lm-ME at $15 \mathrm{~min}$ and at 5,15 , and $30 \mathrm{~min}$, respectively (Figure 3(c)). Further, we checked signaling molecules upstream of mitogen-activated protein kinase kinase proteins (MAPKKs, e.g., MEK1/2, MKK4, MKK3/6, and MKK7). Phospho-MEK1/2, MKK3/6, and MKK7 decreased after $15 \mathrm{~min}$, and phosphor-MKK4 decreased in 5 and $60 \mathrm{~min}$ (Figure 3(d)) after treatment with Lm-ME. MAPKKs were attenuated by Lm-ME, so we checked TAK1, IRAK1, and IRAK4 at earlier time points, because TAK1 is related to the AP-1 pathway and activates MAPKs [32]. Phospho-TAK1 decreased with Lm-ME treatment, but IRAK1 and IRAK4 were not affected by $200 \mu \mathrm{g} / \mathrm{ml} \mathrm{Lm-ME}$ (Figure 3(e)). Together, these data imply that TAK1 may be a target protein of Lm-ME.

\subsection{Anti-Inflammatory Effects of Lm-Me by Targeting Src and} TAK1 Kinases. Based on previous western blotting results, we hypothesized that Src and TAK1 could be targeted by Lm-ME. To test this hypothesis, we utilized a strategy of overexpression of Src and TAK1 and determined whether autophosphorylation of Src and TAK1 and phosphorylation of downstream molecules decreased or not. First, we overexpressed HA-Src for $24 \mathrm{~h}$ in HEK293T cells and then treated the cells with $200 \mu \mathrm{g} / \mathrm{ml}$ of Lm-ME for $24 \mathrm{~h}$. c-Src is autophosphorylated on Tyr-416, a residue in the middle of the carboxyl terminus [33], so we checked the levels of phosphorylated Src and p-p85, which is phosphorylated by p-Src. Following treatment with Lm-ME, p-Src and p-p85 levels decreased (Figure 4(a)). Next, we sought to verify whether Src inhibition could block NO production. We used PP2, which was developed to inhibit Src family members [34]. RAW264.7 cells were pretreated with 10,20 , or $40 \mu \mathrm{M}$ of PP2 for $30 \mathrm{~min}$ and then treated with LPS for $24 \mathrm{~h}$. As measured in the cell culture supernatant, PP2 blocked NO production without cytotoxicity (Figures $4(\mathrm{~b})$ and $4(\mathrm{c})$ ). In the AP-1 pathway, we assumed TAK1 could be the target protein of Lm-ME (Figure 3), so we overexpressed the TAK1 gene in HEK293T cells. TAK1 is also known as an 


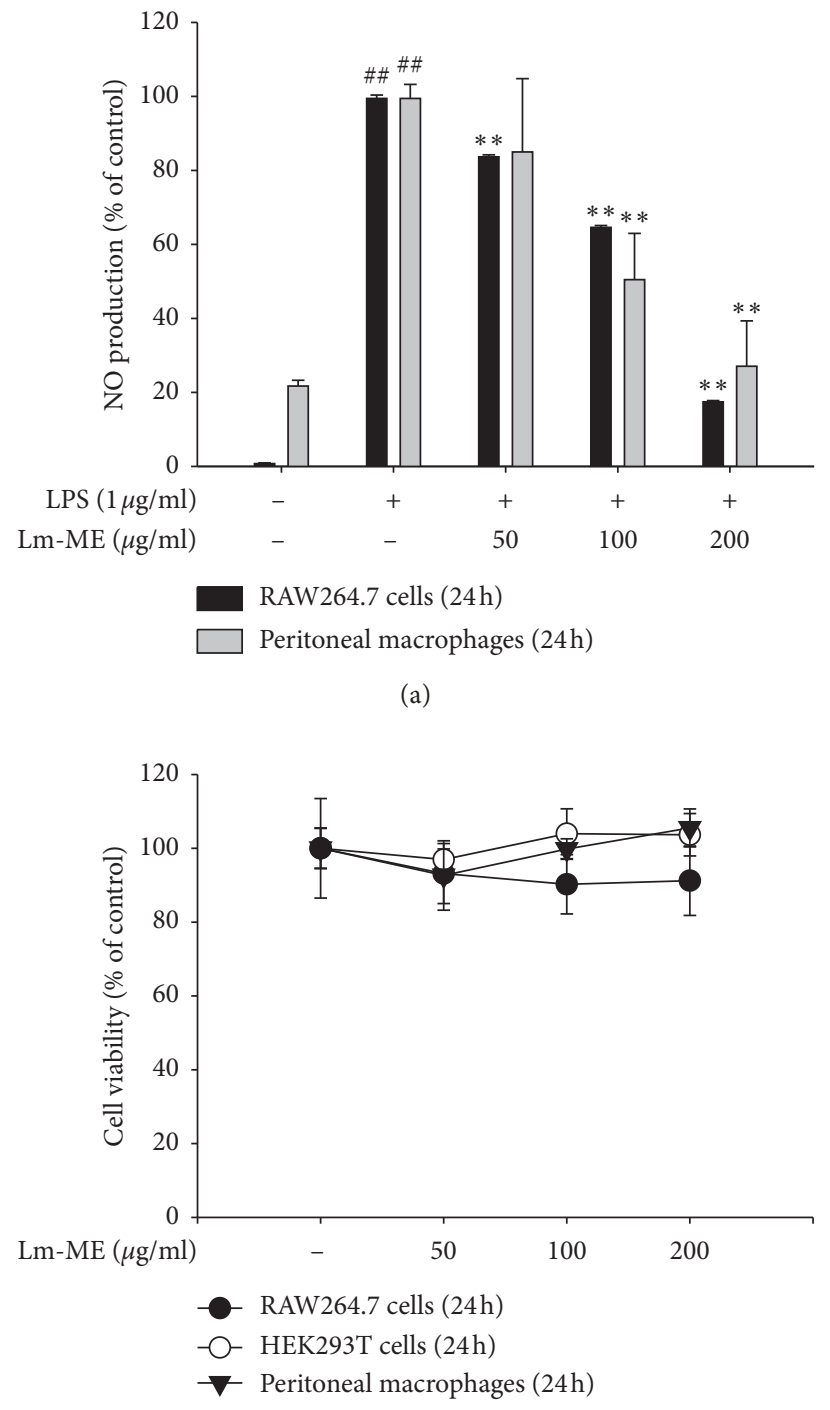

(c)

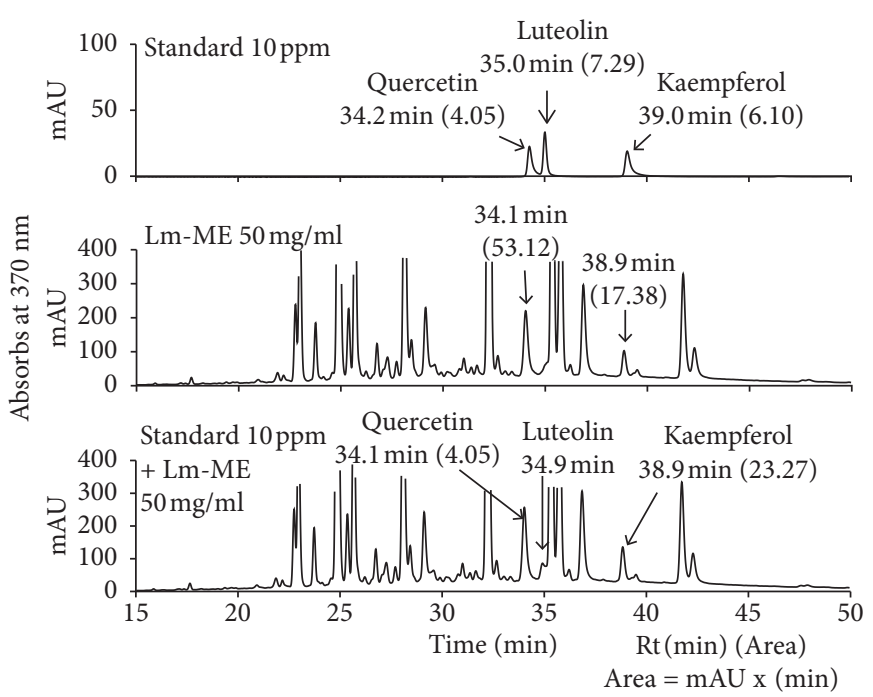

(e)

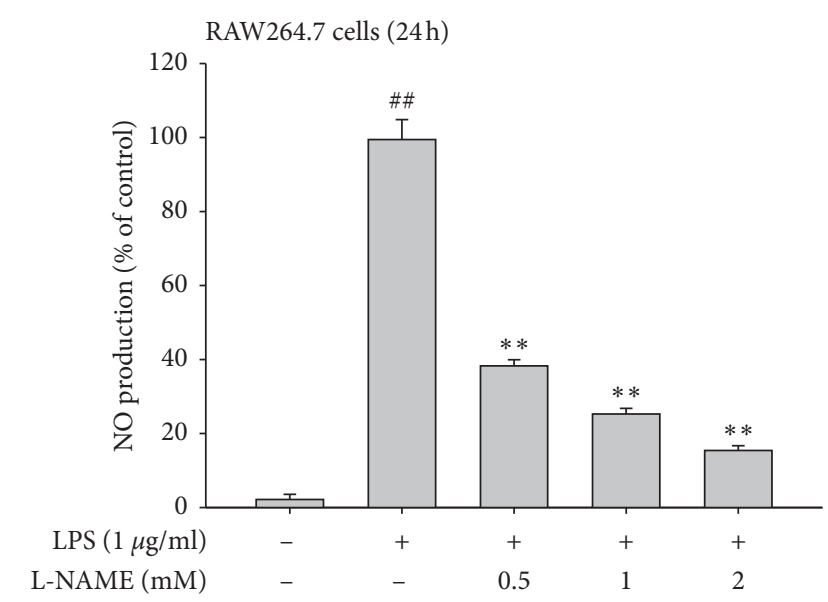

(b)

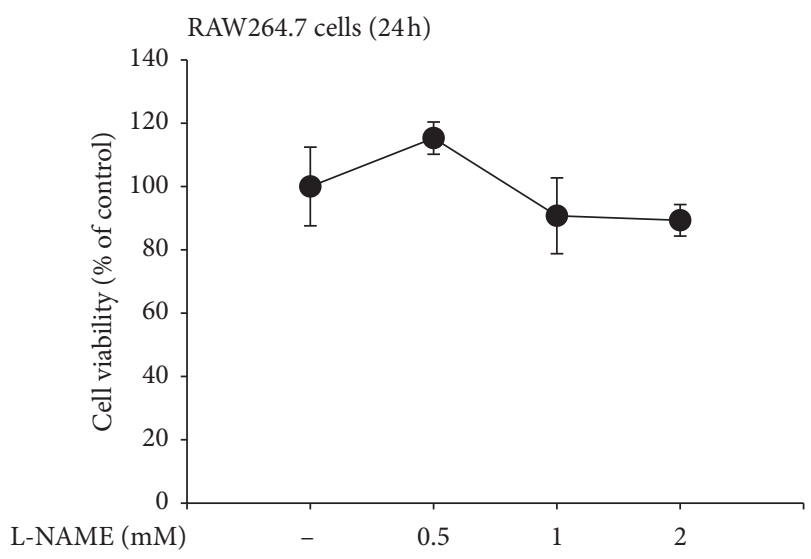

(d)

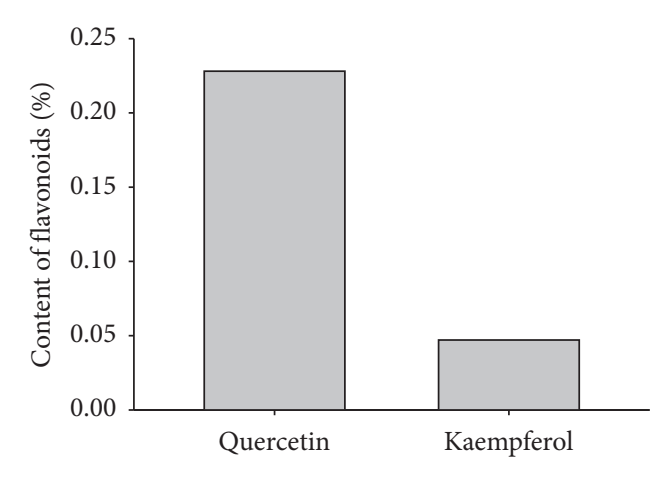

(f)

FIGURE 1: Effects of Lm-ME on NO production and cell viability. (a) Macrophage-like RAW264.7 cells and primary macrophage cells obtained from the peritoneal exudates of thioglycollate- (TG-) injected mice were pretreated with 50, 100, or $200 \mu \mathrm{g} / \mathrm{ml}$ of $\mathrm{Lm}-\mathrm{ME}$ for $30 \mathrm{~min}$ before treatment with LPS for $24 \mathrm{~h} \mathrm{NO}$ production was measured using the cell culture supernatant. (b) RAW264.7 cells were pretreated with 0.5 , 1 , or $2 \mathrm{mM}$ L-NAME and then treated with LPS. After $24 \mathrm{~h}$ incubation, NO collected from cell culture supernatants was measured by Griess solution. (c) RAW264.7 cells, HEK293T cells, and peritoneal macrophages were treated Lm-ME 50, 100, or $200 \mu \mathrm{g} / \mathrm{ml}$. After $24 \mathrm{~h}$, cell viability was measured by MTT assay. (d) Cytotoxicity of L-NAME was determined by MTT assay. (e, f) Components of Lm-ME were analyzed by HPLC. 


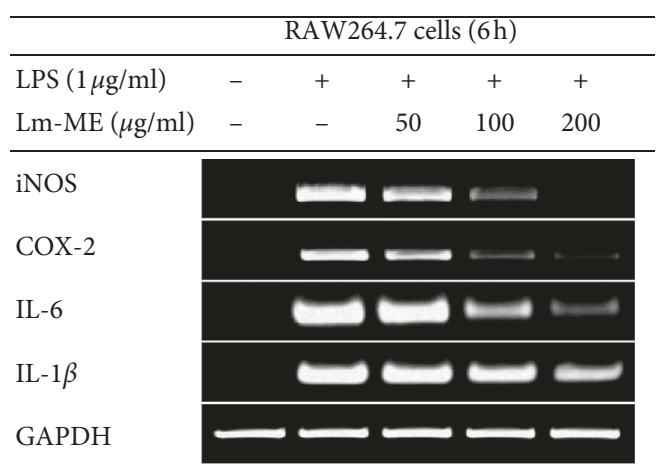

(a)

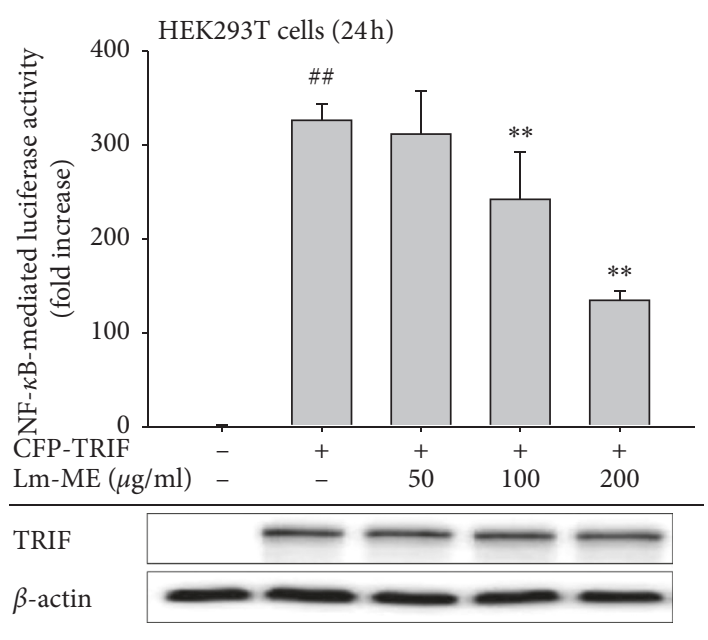

(c)

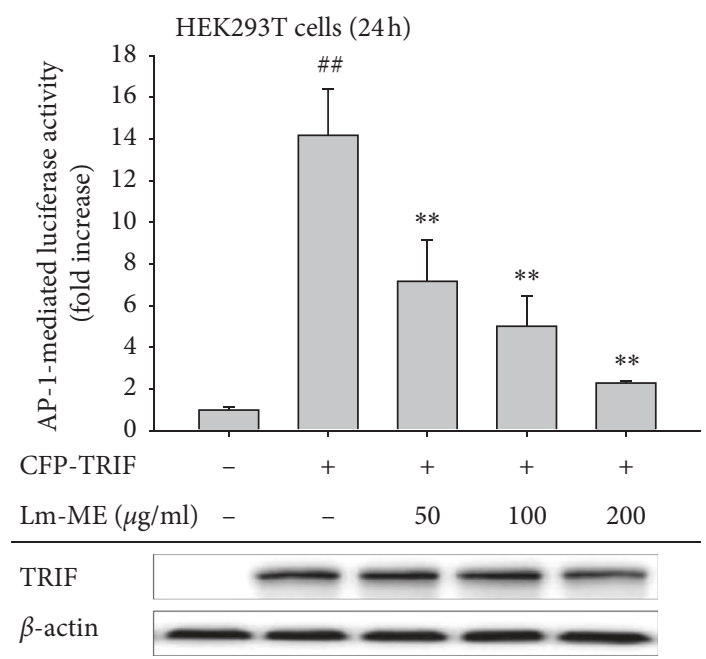

(e)

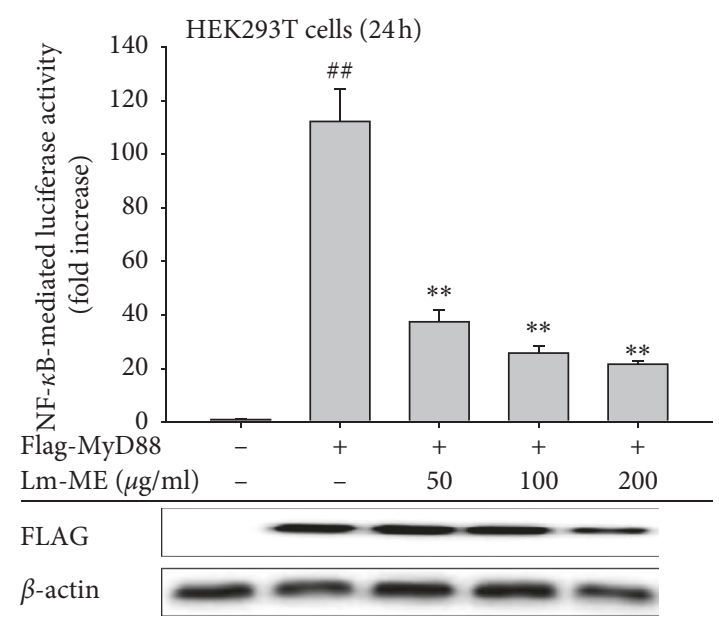

(b)

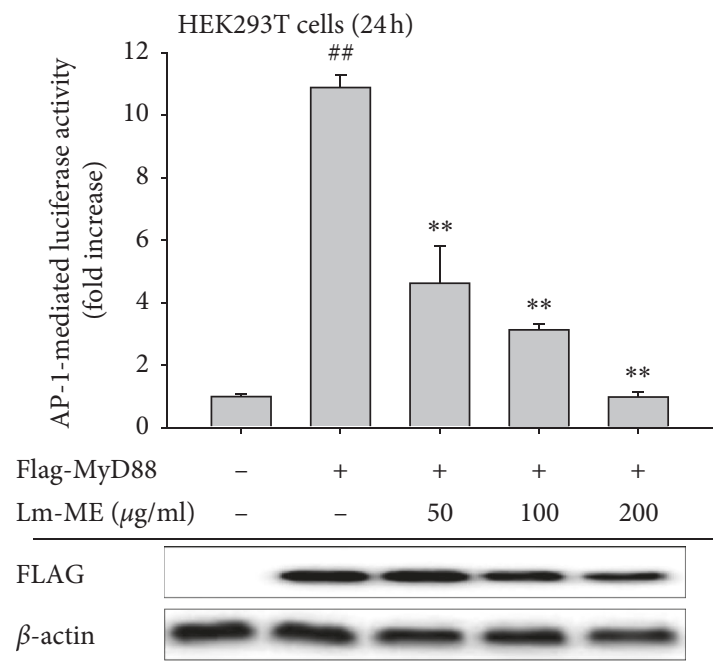

(d)

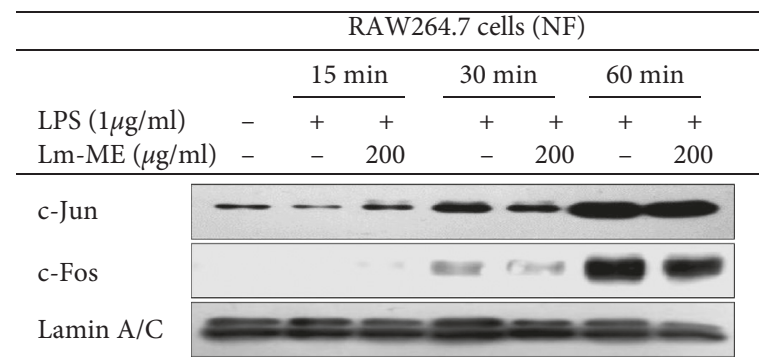

(f)

FIGURE 2: Anti-inflammatory effects of Lm-ME on mRNA expression and transcriptional activity. (a) RAW264.7 cells were pretreated with 50,100 , or $200 \mu \mathrm{g} / \mathrm{ml}$ of Lm-ME and then treated with $1 \mu \mathrm{g} / \mathrm{ml}$ of LPS. After $6 \mathrm{~h}, \mathrm{mRNA}$ was extracted from the cells, and proinflammatory cytokines (iNOS, COX-2, IL-6, and IL-1 $\beta$ ) were evaluated using semiquantitative RT-PCR. (b-e) In 24 wells, HEK293T cells were plated at $1.25 \times 10^{5}$ cells per well. After $24 \mathrm{~h}, \mathrm{NF}-\kappa \mathrm{B}$ or AP-1 luciferase gene and $\beta$-galactosidase-expressing constructs were transfected into HEK293T cells along with either the MyD88 or TRIF gene. After $24 \mathrm{~h}$ incubation, 50,100 , or $200 \mu \mathrm{g} / \mathrm{ml}$ of Lm-ME was added, and NF- $\kappa \mathrm{B}$ luciferase activity was measured by the luminometer. Total form of FLAG and TRIF was determined by western blotting analysis. (d) RAW 264.7 cells were pretreated with $200 \mu \mathrm{g} / \mathrm{ml}$ of Lm-ME for $30 \mathrm{~min}$ and then exposed to $1 \mu \mathrm{g} / \mathrm{ml} \mathrm{LPS} \mathrm{for} \mathrm{15,} \mathrm{30,} \mathrm{or} 60 \mathrm{~min}$. Using western blotting analysis, nuclear c-Jun, and c-Fos levels were determined. 


\begin{tabular}{|c|c|c|c|c|}
\hline \multicolumn{5}{|c|}{$\begin{array}{l}\text { RAW264.7 cells (WCL) } \\
\end{array}$} \\
\hline \multirow{3}{*}{$\begin{array}{l}\text { LPS }(1 \mu \mathrm{g} / \mathrm{ml}) \\
\operatorname{Lm}-\mathrm{ME}(200 \mu \mathrm{g} / \mathrm{ml})\end{array}$} & $5 \mathrm{~min} 15 \mathrm{~min}$ & $30 \mathrm{~min}$ & $60 \mathrm{~min}$ & \\
\hline & $\overline{+\quad+}+$ & $\overline{++}$ & $\overline{+\quad+}$ & \\
\hline & $-\quad-\quad+\quad+$ & $-\quad+$ & $-\quad+$ & \\
\hline $\mathrm{p}-\mathrm{IKK} \alpha / \beta$ & --5 & & & \\
\hline $\mathrm{IKK} \alpha / \beta$ & $-\infty-1-$ & $-\infty$ & $-\infty$ & \\
\hline $\mathrm{p}-\mathrm{I} \kappa \mathrm{B} \alpha$ & -- & & & (Short exposure) \\
\hline $\mathrm{p}-\mathrm{I} \kappa \mathrm{B} \alpha$ & 0 & -- & $-\infty$ & (Long exposure) \\
\hline p-p50 & $\therefore-3-2=$ & 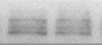 & $3.4=0$ & \\
\hline p50 & $-\infty-\infty$ & $-\infty$ & -1 & \\
\hline p-p65 & 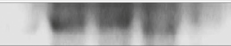 & +31 & 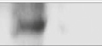 & \\
\hline p65 & ---- & -- & -- & \\
\hline$\beta$-actin & 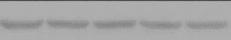 & $-\infty$ & $=$ & \\
\hline
\end{tabular}

(a)

\begin{tabular}{|c|c|c|c|c|}
\hline \multirow{4}{*}{$\begin{array}{l}\text { LPS }(1 \mu \mathrm{g} / \mathrm{ml}) \\
\mathrm{Lm}-\mathrm{ME}(200 \mu \mathrm{g} / \mathrm{ml})\end{array}$} & \multicolumn{4}{|c|}{ RAW264.7 cells (WCL) } \\
\hline & $5 \min$ & $15 \mathrm{~min}$ & $30 \mathrm{~min}$ & $60 \mathrm{~min}$ \\
\hline & $\overline{+\quad+}$ & $\overline{+\quad+}$ & $\overline{+\quad+}$ & $\overline{+\quad+}$ \\
\hline & $-\quad+$ & $-\quad+$ & - & - \\
\hline p-ERK & 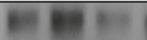 & 14 & at & $8 \pi$ \\
\hline ERK & $-\infty-$ & $=-$ & $\Leftrightarrow=$ & 25 \\
\hline p-JNK & & - & -- & \\
\hline JNK & $-\infty$ & $-\infty$ & $=$ & $-\infty$ \\
\hline p-p38 & --- & -1 & 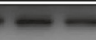 & $5-$ \\
\hline p38 & -- & -- & -1 & --- \\
\hline$\beta$-actin & -1 & - & $-\infty$ & -0 \\
\hline
\end{tabular}

(c)

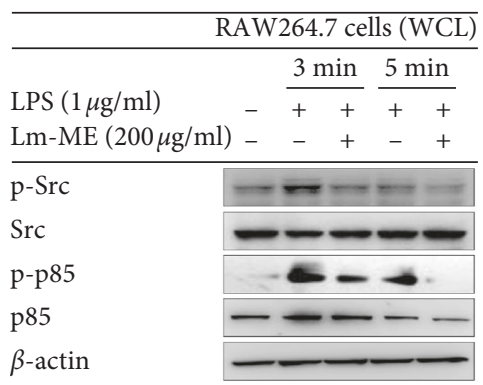

(b)

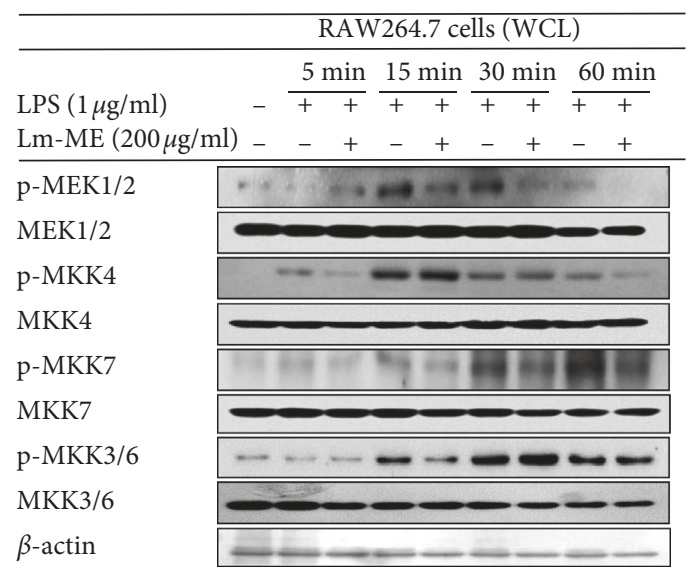

(d)

\begin{tabular}{|c|c|c|c|c|c|c|}
\hline \multirow{5}{*}{$\begin{array}{l}\mathrm{LPS}(1 \mu \mathrm{g} / \mathrm{ml}) \\
\mathrm{Lm}-\mathrm{ME}(200 \mu \mathrm{g} / \mathrm{ml})\end{array}$} & \multirow{2}{*}{\multicolumn{2}{|c|}{$\begin{array}{c}\text { Exp.1 } \\
\text { RAW264.7 cells (WCL) }\end{array}$}} & \multicolumn{4}{|c|}{ Exp.2 } \\
\hline & & & \multicolumn{4}{|c|}{ RAW264.7 cells (WCL) } \\
\hline & \multirow{3}{*}{$\begin{array}{r}3 \mathrm{~min} \\
+\quad+ \\
-\quad+ \\
\end{array}$} & \multirow{3}{*}{$\begin{array}{l}5 \min \\
+\quad+ \\
-\quad+\end{array}$} & \multirow[b]{2}{*}{$\operatorname{LPS}(1 \mu \mathrm{g} / \mathrm{ml})$} & $3 \mathrm{~min}$ & \multicolumn{2}{|c|}{$5 \mathrm{~min}$} \\
\hline & & & & \multirow{2}{*}{$\begin{array}{l}+\quad+ \\
-\quad+ \\
\end{array}$} & \multirow{2}{*}{\multicolumn{2}{|c|}{$\begin{array}{l}+\quad+ \\
-\quad+ \\
\end{array}$}} \\
\hline & & & Lm-ME $(200 \mu \mathrm{g} / \mathrm{ml})$ & & & \\
\hline \multirow{3}{*}{$\begin{array}{l}\text { p-TAK1 } \\
\text { TAK1 } \\
\text { IRAK4 }\end{array}$} & \multicolumn{2}{|c|}{$-\cdots+-\infty$} & \multirow{5}{*}{$\begin{array}{l}\mathrm{p} \text {-TAK1 } \\
\text { TAK1 } \\
\beta \text {-actin }\end{array}$} & \multicolumn{3}{|c|}{ 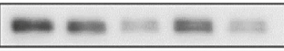 } \\
\hline & \multicolumn{2}{|c|}{$-\infty=0$} & & \multicolumn{3}{|c|}{$--\cdots$} \\
\hline & \multicolumn{2}{|c|}{ 40 } & & \multicolumn{3}{|c|}{ 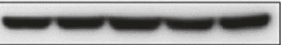 } \\
\hline IRAK1 & \multicolumn{2}{|c|}{$----\square$} & & & & \\
\hline$\beta$-actin & \multicolumn{2}{|c|}{$-\infty=0$} & & & & \\
\hline
\end{tabular}

(e)

FIgURE 3: Inhibitory effects of Lm-ME on the NF- $\kappa$ B and AP-1 pathways. (a) RAW264.7 cells were pretreated $200 \mu \mathrm{g} / \mathrm{ml}$ of Lm-ME for $30 \mathrm{~min}$, followed by $1 \mu \mathrm{g} / \mathrm{ml}$ of LPS for the indicated times $(5,15,30$, or $60 \mathrm{~min})$. Cell lysates were prepared and the phosphorylated and total forms of $\mathrm{IKK} \alpha / \beta, \mathrm{p} 50, \mathrm{p} 65$, and $\mathrm{I} \kappa \mathrm{B} \alpha$ were determined by western blotting analysis. (b) Lm-ME-pretreated RAW264.7 cells were exposed to LPS for the indicated times ( 3 or $5 \mathrm{~min}$ ), and cell lysates were obtained. Phosphorylated and total forms of Src and p 85 were checked by western blotting analysis. (c-e) RAW 264.7 cells were pretreated with $200 \mu \mathrm{g} / \mathrm{ml}$ of $\mathrm{Lm}$-ME and incubated with LPS for the indicated times $(3,5,15,30$, or $60 \mathrm{~min})$. Phosphorylated and total forms of ERK, JNK, p38, MEK1/2, MKK4, MKK3/6, and MKK7 or TAK1, IRAK4, and IRAK1 were determined by western blotting analysis.

autophosphorylated kinase within its activation loop [35]. We determined that phosphorylated TAK1 was activated and that Lm-ME could block autophosphorylation of TAK1. In addition, MKK4, a downstream molecule, was also inhibited by Lm-ME (Figure 4(d)). We further tested whether the TAK1 inhibitor 5Z-7-oxozeaenol could also inhibit NO production. As expected, 5Z-7-oxozeaenol reduced NO production without cytotoxicity (Figures 4(e) and $4(\mathrm{f}))$. Based on these findings, we conclude that Lm-ME can block phosphorylation of Src and TAK1. 


\begin{tabular}{|c|c|}
\hline \multicolumn{2}{|c|}{ HEK293T cells $(48 \mathrm{~h}$} \\
\hline HA-Src & $-\quad+\quad+$ \\
\hline Lm-ME $(200 \mu \mathrm{g} / \mathrm{ml}$ & - \\
\hline HA & -- \\
\hline $\mathrm{p}-\mathrm{Src}$ & 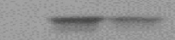 \\
\hline Src & $x=$ \\
\hline p-p85 & 8 \\
\hline$\beta$-actin & $-\infty-$ \\
\hline
\end{tabular}

(a)

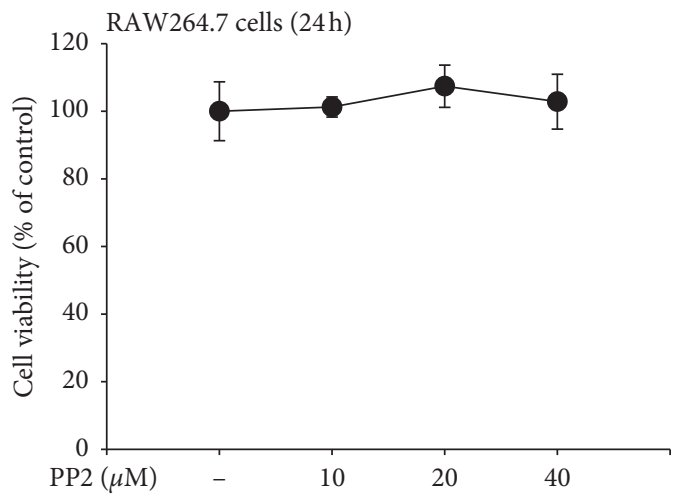

(c)

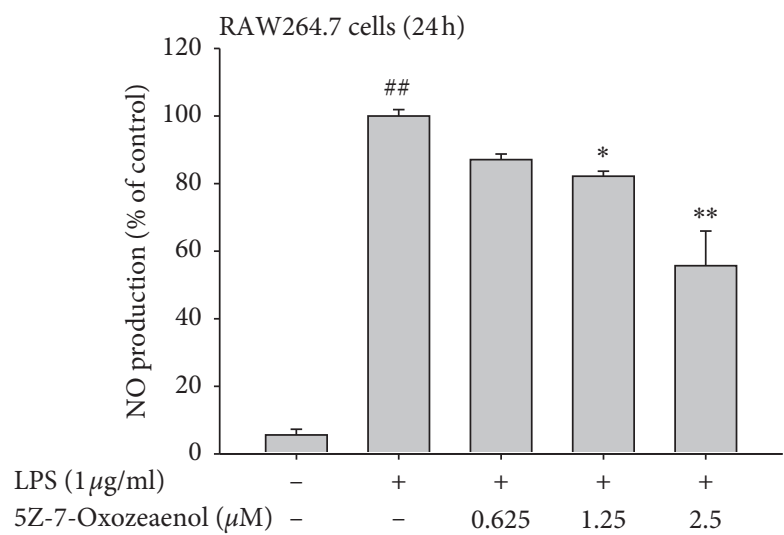

(e)

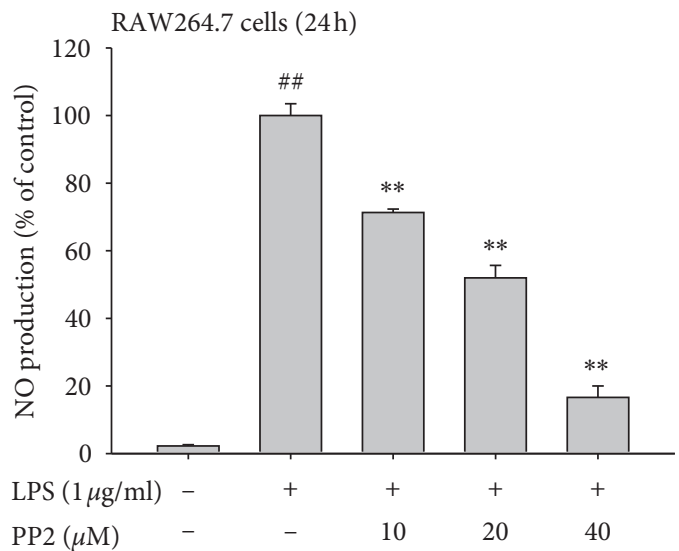

(b)

\begin{tabular}{|c|c|}
\hline \multicolumn{2}{|c|}{ HEK293T cells $(48 \mathrm{~h})$} \\
\hline HA-TAK1 & $-\quad+\quad+$ \\
\hline Lm-ME $(200 \mu \mathrm{g} / \mathrm{ml})$ & - \\
\hline $\mathrm{HA}$ & $m=$ \\
\hline p-TAK1 & - \\
\hline TAK1 & $5=$ \\
\hline p-MKK4 & $=$ \\
\hline MKK4 & $-\infty$ \\
\hline$\beta$-actin & SD \\
\hline
\end{tabular}

(d)

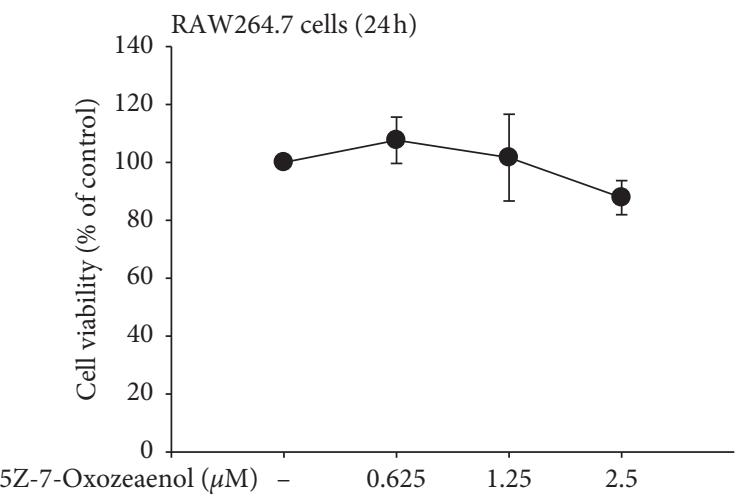

(f)

FIGURE 4: Overexpression of Src and TAK1 can be blocked by Lm-ME. (a) HEK293T cells were transfected with HA-Src constructs for 24h and then divided according to treatment with Lm-ME. By western blotting analysis, total HA and Src and phosphorylated Src and p85 were detected. (b and e) RAW264.7 cells were pretreated with PP2 (an Src family inhibitor) and 5Z-7-oxozeaenol (a TAK1 inhibitor) at different concentrations. After $30 \mathrm{~min}$, LPS was added for $24 \mathrm{~h}$ and the supernatant of RAW264.7 cells reacted with Griess reagents. NO production was measured by spectrophotometer. (c and f) The cytotoxicity of PP2 and 5Z-7-oxozeaenol were examined by MTT assay. (d) HEK293T cells were transfected with an HA-TAK1 expression construct for $24 \mathrm{~h}$ and also treated with Lm-ME for $24 \mathrm{~h}$. Total HA, TAK1, and MKK4 and phosphorylated TAK1 and MKK4 were determined by western blotting analysis.

3.5. Effect of Lm-ME on HCl/EtOH-Induced Acute Gastritis. To investigate whether Lm-ME has pharmacological effects in vivo, the $\mathrm{HCl} / \mathrm{EtOH}$-induced gastritis animal model was employed under oral administration conditions. Since $\mathrm{HCl} /$ EtOH treatment causes injury and ulcer of the stomach,
DAMPs could be released and seem to manage gastric inflammation [36, 37]. Interestingly, it has been reported that DAMP (e.g., ATP and high mobility group protein B1 (HMGB1))-mediated inflammation induces inflammation by interaction with TLRs (e.g., TLR4) and subsequent 


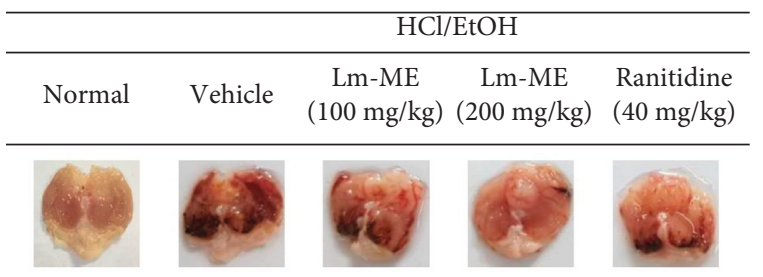

(a)

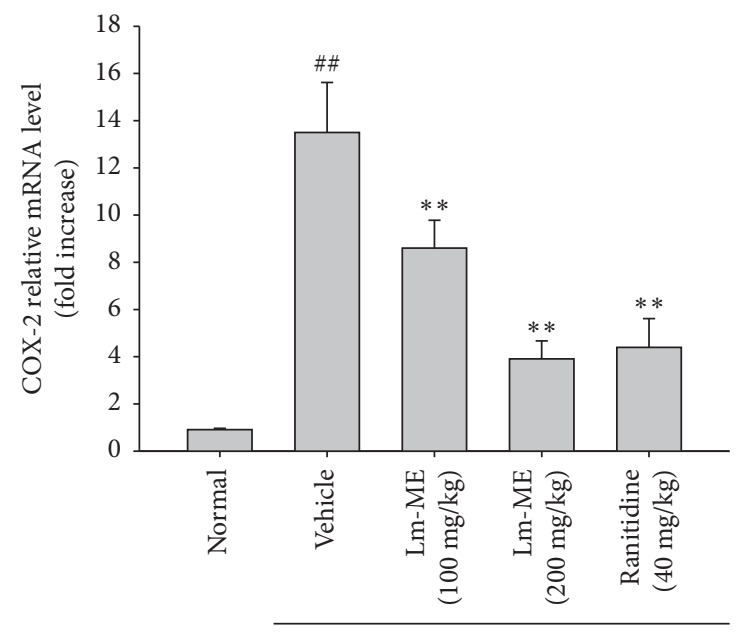

$\mathrm{HCl} / \mathrm{EtOH}$

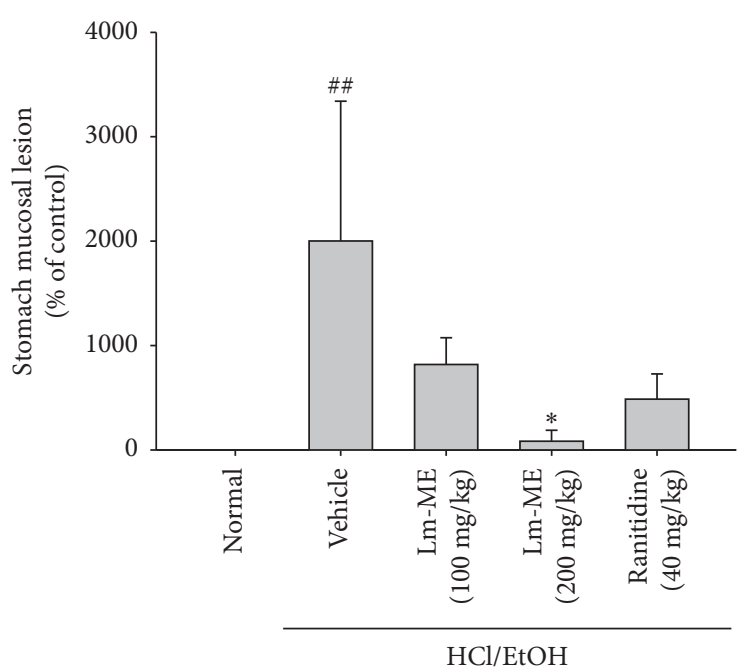

(b)

\begin{tabular}{lccccc} 
& \multicolumn{5}{c}{ Stomach lysates } \\
\hline $\mathrm{HCl} / \mathrm{EtOH}$ & - & + & + & + & + \\
$\mathrm{Lm}-\mathrm{ME}(\mathrm{mg} / \mathrm{kg})$ & - & - & 100 & 200 & - \\
Ranitidine $(\mathrm{mg} / \mathrm{kg})$ & - & - & - & - & 40 \\
\hline
\end{tabular}

p-TAK1

TAK1

$\beta$-actin

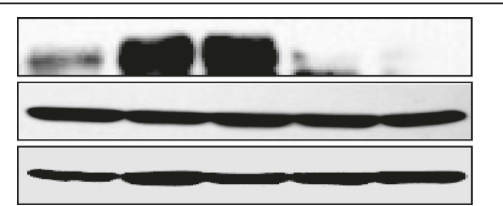

(c)

(d)

FIGURE 5: In vivo anti-inflammatory effects of Lm-ME. ICR mice were orally injected with 0, 100, or $200 \mathrm{mg} / \mathrm{kg} \mathrm{Lm-ME} \mathrm{or} 40 \mathrm{mg} / \mathrm{kg}$ of ranitidine 3 times over 2 days. Eight hours after the last oral injection, $300 \mu \mathrm{l}$ of $150 \mathrm{mM} \mathrm{HCl} / 60 \% \mathrm{EtOH}$ was orally administrated for $1 \mathrm{~h}$. Stomachs were excised from the mice, and stomach lesions imaged (a). By using Image J software, stomach lesions induced by $\mathrm{HCl} / \mathrm{EtOH}$ were measured (b). (c) mRNA expression levels of COX-2 from gastritis samples were measured by quantitative real-time PCR. (d) Total and phosphorylated TAK1 levels from gastritis mice were determined by western blotting analysis.

activation of the MyD88-dependent NF- $\kappa \mathrm{B}$ signaling pathway [36]. In the end, DAMPs can induce inflammatory cytokines such as IL-6, IL-1 $\beta$, and TNF- $\alpha$ [38]. So, we used $\mathrm{HCl} / \mathrm{EtOH}$-induced gastritis model to check anti-inflammatory effect of Lm-ME. The $200 \mathrm{mg} / \mathrm{kg} \mathrm{Lm}-\mathrm{ME}$ group had the fewest stomach inflammatory blood lesions compared to $100 \mathrm{mg} / \mathrm{kg} \mathrm{Lm}-\mathrm{ME}$ and ranitidine (Figure 5(a)). In gastritis stomach samples, the level of COX-2 mRNA decreased after treatment with $200 \mathrm{mg} / \mathrm{kg}$ Lm-ME (Figure 5(c)). We next analyzed gastritis protein levels of TAK1 in its total and phosphorylated forms. Phosphorylated TAK1 was decreased by treatment with $200 \mathrm{mg} / \mathrm{kg} \mathrm{Lm}-\mathrm{ME}$ and $40 \mathrm{mg} / \mathrm{kg}$ ranitidine (Figure 5(d)). In conclusion, LmME alleviated acute gastritis symptoms by inhibition of TAK1.

\section{Discussion}

The genus Licania displays the largest number of biological activities among Chrysobalanaceae species and is used widely in Venezuela for anti-inflammatory properties [39]. In Northeastern Brazil, Licania leaves have been used to treat diabetes, stomach aches, diarrhea, and dysentery [20]. However, the underlying anti-inflammatory mechanisms in Lm-ME in LPS-induced RAW264.7 cells and an $\mathrm{HCl} / \mathrm{EtOH}$ induced acute gastritis model have not previously been reported. Therefore, this study focused on the effects and molecular target proteins of Lm-ME to better illuminate anti-inflammatory molecular mechanisms.

When RAW264.7 cells and peritoneal macrophages are treated with LPS, they produce NO [40]. We observed that 


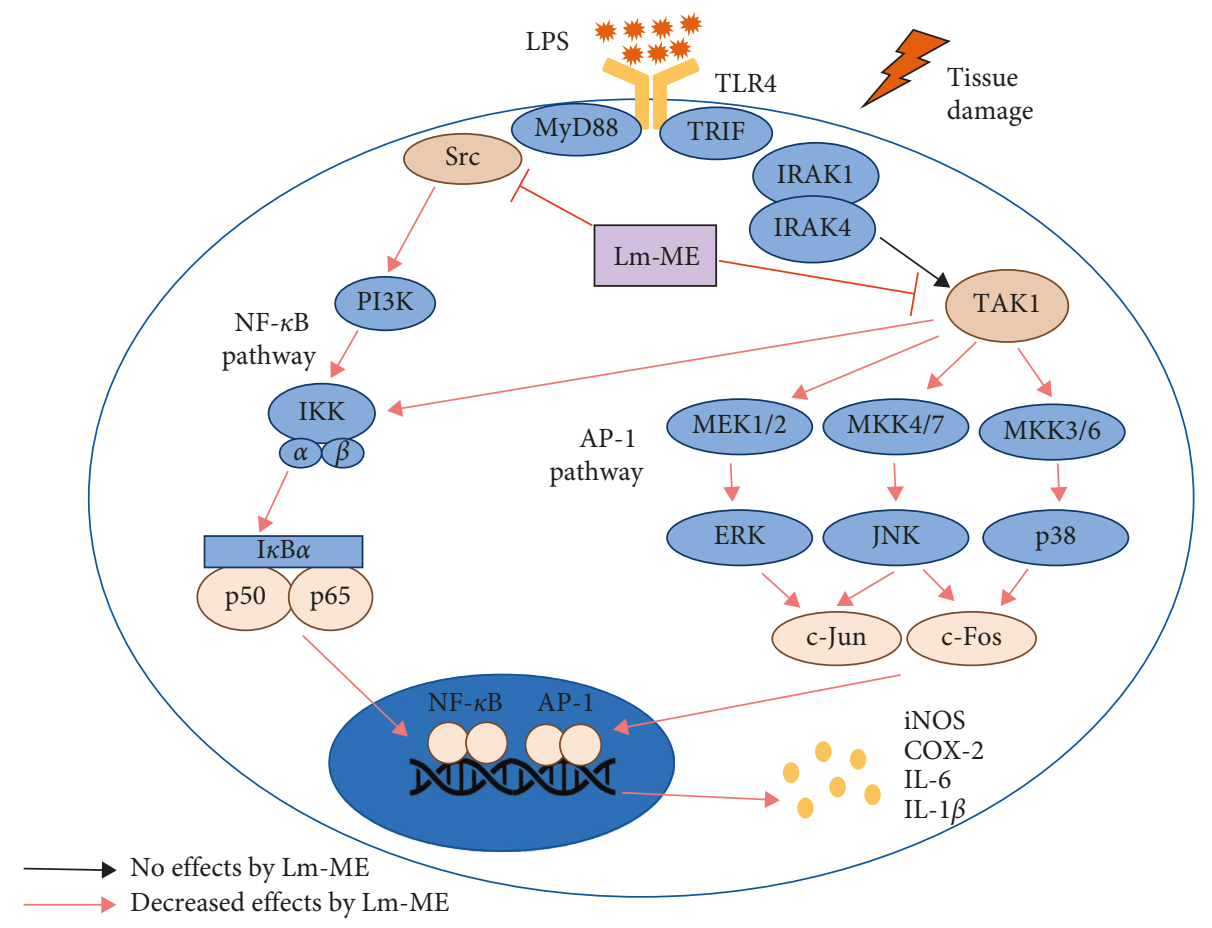

Figure 6: Anti-inflammatory mechanisms of Lm-ME. Lm-ME targeted Src and TAK1 kinases in inflammatory NF- $\kappa$ B and AP-1 pathways. Consequently, the activation of transcription factors was blocked, and various inflammatory cytokines and mediators were reduced.

NO production was reduced by Lm-ME (Figure 1(a)) without any cytotoxicity in various LPS-stimulated cell types (Figure 1(b)). These results indicate that Lm-ME can have anti-inflammatory effects on macrophage-like RAW264.7 cells and peritoneal macrophages. Lm-ME significantly decreased mRNA levels of proinflammatory cytokines such as iNOS, COX-2, IL-6, and IL- $1 \beta$ in LPS-induced RAW264.7 cells (Figure 2(a)). These proinflammatory cytokines are related to inflammatory pain and disease [16]. IL- $1 \beta$ cytokines and IL- 6 are related to rheumatologic autoimmune diseases, and many treatment strategies have targeted cytokine production. In addition, NO release and iNOS expression can be caused by osteoarthritis and systemic lupus erythematosus (SLE), as well as various types of intestinal inflammation [41]. We found that the $\mathrm{HCl} / \mathrm{EtOH}$-induced acute gastritis model of damage-associated inflammatory disease was palliated by Lm-ME, which reduced the mRNA levels of COX-2 and protein levels of phosphorylated TAK1 (Figures 5(c) and 5(d)). The regulatory effects of Lm-ME on NO production and expression of other cytokines suggest the possibility that Lm-ME can be used as an effective alternative remedy in inflammatory-related disorders.

Flavonoids are polyphenolic compounds that occur ubiquitously in plants, and they have been found to have antioxidant, antiplatelet, antiviral, antiulcerogenic, antimicrobial, antihypertensive, and anti-inflammatory activities. Kaempferol, quercetin, and myricetin are well known flavonols that have a 3-hydroxyflavone backbone and antiinflammatory effects [42-45]. Accordingly, we checked the active components of Lm-ME and found ample quercetin and kaempferol (Figures 1(e) and 1(f)). Quercetin and kaempferol are reported to reduce iNOS, COX-2, reactive c-protein, and NF- $\kappa \mathrm{B}$ pathway signaling molecules [43]. Our findings are in agreement with noted inhibition effects of Lm-ME on mRNA production (Figure $2(\mathrm{a})$ ), NF- $\kappa \mathrm{B}$ luciferase activity (Figure 2(b)), and active forms of NF- $\kappa \mathrm{B}$ transcription factors p50 and p65 (Figure 3(a)).

Interestingly, Lm-ME targeted Src tyrosine kinase by blocking autophosphorylation of $\mathrm{Src}$ and suppressing downstream signaling molecules $\mathrm{PI} 3 \mathrm{~K}, \mathrm{IKK} \alpha / \beta, \mathrm{I} \kappa \mathrm{B} \alpha, \mathrm{p} 50$, and p65 (Figures 3(a) and 3(b)). Central role of Src in controlling inflammatory signaling cascades for NF- $\kappa \mathrm{B}$ activation has been previously reported $[46,47]$. Due to the functional response of Src in inflammatory signaling, inflammation-regulatory activities of Src including cytokine production, migration of macrophages, and inflammatory mediator production have been also found in LPS-treated macrophages $[48,49]$. Several compounds or extracts with Src inhibitory property were also proved as anti-inflammatory reagents $[14,50-53]$. In the AP-1 pathway, LmME suppressed activation of only TAK1 and not IRAK1 and IRAK4 (Figure 3(e)). IRAK is membrane associated as part of a complex (IRAK-TRAF6-TAK1-TAB2-TAB3). The important step in inflammation signaling requires IRAK1 to be consecutively phosphorylated on threonine 209, ubiquitinated and degraded. This step allows the TRAF6-TAK1TAB2-TAB3 complex to translocate from the membrane to the cytosol, and degradation is a necessary step in activation of the TAK1-dependent pathway $[54,55]$. TAK1 plays roles in both $\mathrm{NF}-\kappa \mathrm{B}$ and $\mathrm{AP}-1$ pathways, which phosphorylate and activate IKK and MKK6 (an upstream molecule of JNK and p38) [56]. Indeed, it was reported that TAK1 inhibitor 5Z-7-oxozeaenol can prevent picryl chloride-induced ear swelling [57]. Some anti-inflammatory plants or compounds 
such as Momordica charantia and torilin were found to suppress TAK1 as a pharmacological target $[12,58]$, implying that this enzyme plays a positive role in inflammatory responses. Lm-ME suppressed the activation of TAK1 in both LPS/TLR4-activated macrophages (Figure 3(e)) and in $\mathrm{HCl} / \mathrm{EtOH}$-induced gastritis symptom (Figure 5(d)), so it is possible that the observed downregulation of $\mathrm{IKK} \alpha / \beta$ resulted from both Src and TAK1 inhibition.

In conclusion, we found that Lm-ME exerted anti-inflammatory effects by targeting Src- and TAK1-dependent pathways. Lm-ME decreased NO production and transcription of proinflammatory cytokines in vitro and also reduced stomach lesions, levels of COX-2 mRNA, and phosphorylated TAK1 in an $\mathrm{HCl} / \mathrm{EtOH}$-induced gastritis model in vivo. Based on these findings, L. macrocarpa Cuatrec could be a useful herbal medicine for the prevention of Src- and TAK1-related inflammatory diseases (Figure 6).

\section{Data Availability}

The data used to support the findings of this study are available from the corresponding author upon request.

\section{Conflicts of Interest}

The authors have no conflicts of interest to declare.

\section{Authors' Contributions}

Kon Kuk Shin, Sunggyu Kim, Eunji Kim, and Jae Youl Cho designed the experiments. Kon Kuk Shin, Jae Gwang Park, Yo Han Hong, and Sang Hee Park performed the laboratory assays. Kon Kuk Shin, Nur Aziz, Sunggyu Kim, Eunji Kim, and Jae Youl Cho analyzed the data. Kon Kuk Shin, Sunggyu Kim, Eunji Kim, and Jae Youl Cho wrote the manuscript. All authors read and approved the manuscript.

\section{Acknowledgments}

This research was supported by Basic Science Research Programs (2017R1A6A1A03015642) through the National Research Foundation of Korea (NRF) funded by the Ministry of Education, Republic of Korea.

\section{References}

[1] P. Libby, "Inflammatory mechanisms: the molecular basis of inflammation and disease," Nutrition Reviews, vol. 65, no. 12, pp. S140-S146, 2007.

[2] P. J. Barnes, "Chronic obstructive pulmonary disease: effects beyond the lungs," PLoS Medicine, vol. 7, no. 3, Article ID e1000220, 2010.

[3] J. H. Kim, Y.-S. Yi, M.-Y. Kim, and J. Y. Cho, "Role of ginsenosides, the main active components of Panax ginseng, in inflammatory responses and diseases," Journal of Ginseng Research, vol. 41, no. 4, pp. 435-443, 2017.

[4] R. S. Mahla, C. M. Reddy, D. V. Prasad, and H. Kumar, "Sweeten PAMPs: role of sugar complexed PAMPs in innate immunity and vaccine biology," Frontiers in Immunology, vol. 4, p. 248, 2013.
[5] C. Truyens and Y. Carlier, Protective Host Response to Trypanosoma Cruzi and its Limitations, American Trypanosomiasis Chagas Disease, Elsevier, Amsterdam, Netherlands, 2017.

[6] Y. Delneste, C. Beauvillain, and P. Jeannin, "Immunité naturelle," Médecine/Sciences, vol. 23, no. 1, pp. 67-74, 2007.

[7] M. S. Hayden and S. Ghosh, "NF- $\kappa$ B in immunobiology," Cell Research, vol. 21, no. 2, pp. 223-244, 2011.

[8] D. M. Rocha, A. P. Caldas, L. L. Oliveira, J. Bressan, and H. H. Hermsdorff, "Saturated fatty acids trigger TLR4-mediated inflammatory response," Atherosclerosis, vol. 244, pp. 211-215, 2016.

[9] J. Deguine and G. M. Barton, "MyD88: a central player in innate immune signaling," F1000Prime Reports, vol. 6, 2014.

[10] S. K. Manna and B. B. Aggarwal, "Wortmannin inhibits activation of nuclear transcription factors NF- $\kappa \mathrm{B}$ and activated protein-1 induced by lipopolysaccharide and phorbol ester," FEBS Letters, vol. 473, no. 1, pp. 113-118, 2000.

[11] T. Kawai and S. Akira, "Signaling to NF- $\kappa$ B by toll-like receptors," Trends in Molecular Medicine, vol. 13, no. 11, pp. 460-469, 2007.

[12] M. Endale, T.-H. Kim, Y.-S. Kwak et al., "Torilin inhibits inflammation by limiting TAK1-mediated MAP kinase and NF- $\kappa$ B activation," Mediators of Inflammation, vol. 2017, Article ID 7250968, 13 pages, 2017.

[13] J.-O. Lee, E. Choi, K. K. Shin et al., "Compound K, a ginsenoside metabolite, plays an antiinflammatory role in macrophages by targeting the AKT1-mediated signaling pathway," Journal of Ginseng Research, vol. 43, no. 1, pp. 154-160, 2019.

[14] H. G. Kim, S. Choi, J. Lee et al., "Src is a prime target inhibited by celtis choseniana methanol extract in its anti-inflammatory action," Evidence-Based Complementary and Alternative Medicine, vol. 2018, Article ID 3909038, , 2018.

[15] S. T. Hunto, K. K. Shin, H. G. Kim et al., "Phosphatidylinositide 3-kinase contributes to the anti-inflammatory effect of Abutilon crispum L. Medik methanol extract," EvidenceBased Complementary and Alternative Medicine, vol. 2018, Article ID 1935902, 10 pages, 2018.

[16] J.-M. Zhang and J. An, "Cytokines, inflammation, and pain," International Anesthesiology Clinics, vol. 45, no. 2, pp. 27-37, 2007.

[17] P. Lirk, G. Hoffmann, and J. Rieder, "Inducible nitric oxide synthase-time for reappraisal," Current Drug Target -Inflammation \& Allergy, vol. 1, no. 1, pp. 89-108, 2002.

[18] R. Pahwa and I. Jialal, Chronic Inflammation, StatPearls Publishing, Treasure Island, FL, USA, 2018.

[19] O. Estrada, W. Contreras, G. Acha et al., "Chemical constituents from Licania cruegeriana and their cardiovascular and antiplatelet effects," Molecules, vol. 19, no. 12, pp. 21215-21225, 2014.

[20] E. A. Feitosa, H. S. Xavier, and K. P. Randau, "Chrysobalanaceae: traditional uses, phytochemistry and pharmacology," Revista Brasileira de Farmacognosia, vol. 22, no. 5, pp. 1181-1186, 2012.

[21] D. Gerlier and N. Thomasset, "Use of MTT colorimetric assay to measure cell activation," Journal of Immunological Methods, vol. 94, no. 1-2, pp. 57-63, 1986.

[22] M. J. Hossen, S. H. Jeon, S. C. Kim et al., "In vitro and in vivo antiinflammatory activity of Phyllanthus acidus methanolic extract," Journal of Ethnopharmacology, vol. 168, pp. 217-228, 2015.

[23] S. Y. Han, J. Kim, E. Kim et al., "AKT-targeted anti-inflammatory activity of Panax ginseng calyx ethanolic extract," Journal of Ginseng Research, vol. 42, no. 4, pp. 496-503, 2018. 
[24] T. Yu, J. Lee, Y. G. Lee et al., "In vitro and in vivo anti-inflammatory effects of ethanol extract from Acer tegmentosum," Journal of Ethnopharmacology, vol. 128, no. 1, pp. 139-147, 2010.

[25] E. Kim, Y.-G. Kang, J. Kim et al., "The antioxidant and antiinflammatory activities of 8-hydroxydaidzein (8-HD) in activated macrophage-like RAW264.7 cells," International Journal of Molecular Sciences, vol. 19, no. 7, p. 1828, 2018.

[26] K. L. Green, G. J. Gatto, and K. A. Grant, "The nitric oxide synthase inhibitor l-NAME ( $\mathrm{N} \omega$-nitro-L-arginine methyl ester) does not produce discriminative stimulus effects similar to ethanol," Alcoholism: Clinical and Experimental Research, vol. 21, no. 3, pp. 483-488, 1997.

[27] N. Aziz, M.-Y. Kim, and J. Y. Cho, "Anti-inflammatory effects of luteolin: a review of in vitro, in vivo, and in silico studies," Journal of Ethnopharmacology, vol. 225, pp. 342358, 2018.

[28] T.-T. Wu, T.-L. Chen, and R.-M. Chen, "Lipopolysaccharide triggers macrophage activation of inflammatory cytokine expression, chemotaxis, phagocytosis, and oxidative ability via a toll-like receptor 4-dependent pathway: validated by RNA interference," Toxicology Letters, vol. 191, no. 2-3, pp. 195-202, 2009.

[29] V. Piras and K. Selvarajoo, "Beyond MyD88 and TRIF pathways in Toll-like receptor signaling," Frontiers in Immunology, vol. 5, p. 70, 2014.

[30] K. Burns, F. Martinon, C. Esslinger et al., "MyD88, an adapter protein involved in interleukin-1 signaling," Journal of Biological Chemistry, vol. 273, no. 20, pp. 12203-12209, 1998.

[31] H. S. Lee, C. Moon, H. W. Lee, E.-M. Park, M.-S. Cho, and J. L. Kang, "Src tyrosine kinases mediate activations of NF- $\kappa \mathrm{B}$ and integrin signal during lipopolysaccharide-induced acute lung injury," The Journal of Immunology, vol. 179, no. 10, pp. 7001-7011, 2007.

[32] H. Sakurai, "Targeting of TAK1 in inflammatory disorders and cancer," Trends in Pharmacological Sciences, vol. 33, no. 10, pp. 522-530, 2012.

[33] M. Osusky, S. J. Taylor, and D. Shalloway, "Autophosphorylation of purified c-Src at its primary negative regulation site," Journal of Biological Chemistry, vol. 270, no. 43, pp. 25729-25732, 1995.

[34] H. McLauchlan, M. Elliott, and P. Cohen, “The specificities of protein kinase inhibitors: an update," Biochemical Journal, vol. 371, no. 1, pp. 199-204, 2003.

[35] K. Kishimoto, K. Matsumoto, and J. Ninomiya-Tsuji, “TAK1 mitogen-activated protein kinase kinase kinase is activated by autophosphorylation within its activation loop," Journal of Biological Chemistry, vol. 275, no. 10, pp. 7359-7364, 2000.

[36] N. N. Kuzmich, K. V. Sivak, V. N. Chubarev, Y. Porozov, T. Savateeva-Lyubimova, and F. Peri, "TLR4 signaling pathway modulators as potential therapeutics in inflammation and sepsis," Vaccines, vol. 5, no. 4, p. 34, 2017.

[37] M. Magna and D. S. Pisetsky, "The role of HMGB1 in the pathogenesis of inflammatory and autoimmune diseases," Molecular Medicine, vol. 20, no. 1, pp. 138-146, 2014.

[38] T. Liu, L. Zhang, D. Joo, and S.-C. Sun, "NF- $\kappa$ B signaling in inflammation," Signal Transduction and Targeted Therapy, vol. 2, no. 1, p. 17023, 2017.

[39] J. Mendez, A. R. Bilia, and I. Morelli, "Phytochemical investigations of Licania genus. Flavonoids and triterpenoids from Licania pittieri," Pharmaceutica Acta Helvetiae, vol. 70, no. 3, pp. 223-226, 1995.

[40] J. Wang and G. Mazza, "Inhibitory effects of anthocyanins and other phenolic compounds on nitric oxide production in LPS/
IFN- $\gamma$-activated RAW 264.7 macrophages," Journal of Agricultural and Food Chemistry, vol. 50, no. 4, pp. 850-857, 2002.

[41] R. Zamora, Y. Vodovotz, and T. R. Billiar, "Inducible nitric oxide synthase and inflammatory diseases," Molecular Medicine, vol. 6, no. 5, pp. 347-373, 2000.

[42] M. Comalada, D. Camuesco, S. Sierra et al., "In vivoquercitrin anti-inflammatory effect involves release of quercetin, which inhibits inflammation through down-regulation of the NF- $\kappa \mathrm{B}$ pathway," European Journal of Immunology, vol. 35, no. 2, pp. 584-592, 2005.

[43] V. García-Mediavilla, I. Crespo, P. S. Collado et al., "The antiinflammatory flavones quercetin and kaempferol cause inhibition of inducible nitric oxide synthase, cyclooxygenase- 2 and reactive C-protein, and down-regulation of the nuclear factor kappaB pathway in Chang liver cells," European Journal of Pharmacology, vol. 557, no. 2-3, pp. 221-229, 2007.

[44] L. Kong, C. Luo, X. Li, Y. Zhou, and H. He, "The anti-inflammatory effect of kaempferol on early atherosclerosis in high cholesterol fed rabbits," Lipids in Health and Disease, vol. 12, no. 1, p. 115, 2013.

[45] B. O. Cho, H. H. Yin, S. H. Park, E. B. Byun, H. Y. Ha, and S. I. Jang, "Anti-inflammatory activity of myricetin from Diospyros lotus through suppression of NF- $\kappa$ B and STAT1 activation and Nrf2-mediated HO-1 induction in lipopolysaccharide-stimulated RAW264.7 macrophages," Bioscience, Biotechnology, and Biochemistry, vol. 80, no. 8, pp. 1520-1530, 2016.

[46] J. Mitchell, S. J. Kim, A. Seelmann et al., "Src family kinase tyrosine phosphorylates Toll-like receptor 4 to dissociate MyD88 and Mal/Tirap, suppressing LPS-induced inflammatory responses," Biochemical Pharmacology, vol. 147, pp. 119-127, 2018.

[47] J. Y. Kim, Y. G. Lee, M.-Y. Kim et al., "Src-mediated regulation of inflammatory responses by actin polymerization," Biochemical Pharmacology, vol. 79, no. 3, pp. 431-443, 2010.

[48] M.-C. Maa, M. Y. Chang, Y.-J. Chen et al., "Requirement of inducible nitric-oxide synthase in lipopolysaccharide-mediated Src induction and macrophage migration," Journal of Biological Chemistry, vol. 283, no. 46, pp. 31408-31416, 2008.

[49] T.-H. Leu, S. Charoenfuprasert, C.-K. Yen, C.-W. Fan, and M.-C. Maa, "Lipopolysaccharide-induced c-Src expression plays a role in nitric oxide and $\mathrm{TNF} \alpha$ secretion in macrophages," Molecular Immunology, vol. 43, no. 4, pp. 308-316, 2006.

[50] W. S. Yang, J. Lee, T. W. Kim et al., "Src/NF- $\kappa$ B-targeted inhibition of LPS-induced macrophage activation and dextran sodium sulphate-induced colitis by Archidendron clypearia methanol extract," Journal of Ethnopharmacology, vol. 142, no. 1, pp. 287-293, 2012.

[51] S. E. Byeon, Y. S. Yi, J. Oh, B. C. Yoo, S. Hong, and J. Y. Cho, "The role of Src kinase in macrophage-mediated inflammatory responses," Mediators of Inflammation, vol. 2012, Article ID 512926, 18 pages, 2012.

[52] N. Y. Sung, M.-Y. Kim, and J. Y. Cho, "Scutellarein reduces inflammatory responses by inhibiting Src kinase activity," The Korean Journal of Physiology \& Pharmacology, vol. 19, no. 5, pp. 441-449, 2015.

[53] G. Park, E. Kim, Y.-J. Son et al., "Anti-inflammatory effect of torilidis fructus ethanol extract through inhibition of Src," Pharmaceutical Biology, vol. 55, no. 1, pp. 2074-2082, 2017.

[54] W. Cui, N. Xiao, H. Xiao et al., " $\beta$-TrCP-Mediated IRAK1 degradation releases TAK1-TRAF6 from the membrane to the cytosol for TAK1-dependent NF- $\kappa \mathrm{B}$ activation," Molecular and Cellular Biology, vol. 32, no. 19, pp. 3990-4000, 2012. 
[55] M. J. Hossen, Y. D. Hong, K.-S. Baek et al., "In vitro antioxidative and anti-inflammatory effects of the compound K-rich fraction BIOGF1K, prepared from Panax ginseng," Journal of Ginseng Research, vol. 41, no. 1, pp. 43-51, 2017.

[56] C. Wang, L. Deng, M. Hong, G. R. Akkaraju, J.-I. Inoue, and Z. J. Chen, "TAK1 is a ubiquitin-dependent kinase of MKK and IKK," Nature, vol. 412, no. 6844, pp. 346-351, 2001.

[57] J. Ninomiya-Tsuji, T. Kajino, K. Ono et al., "A resorcylic acid lactone, 5Z-7-oxozeaenol, prevents inflammation by inhibiting the catalytic activity of TAK1 MAPK kinase kinase," Journal of Biological Chemistry, vol. 278, no. 20, pp. 1848518490, 2003.

[58] W. S. Yang, E. Yang, M.-J. Kim et al., "Momordica charantia inhibits inflammatory responses in murine macrophages via suppression of TAK1," The American Journal of Chinese Medicine, vol. 46, no. 2, pp. 435-452, 2018. 


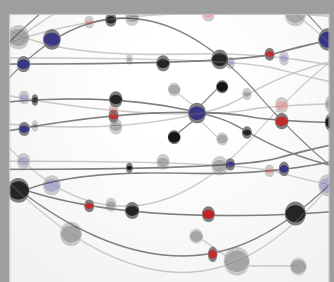

The Scientific World Journal
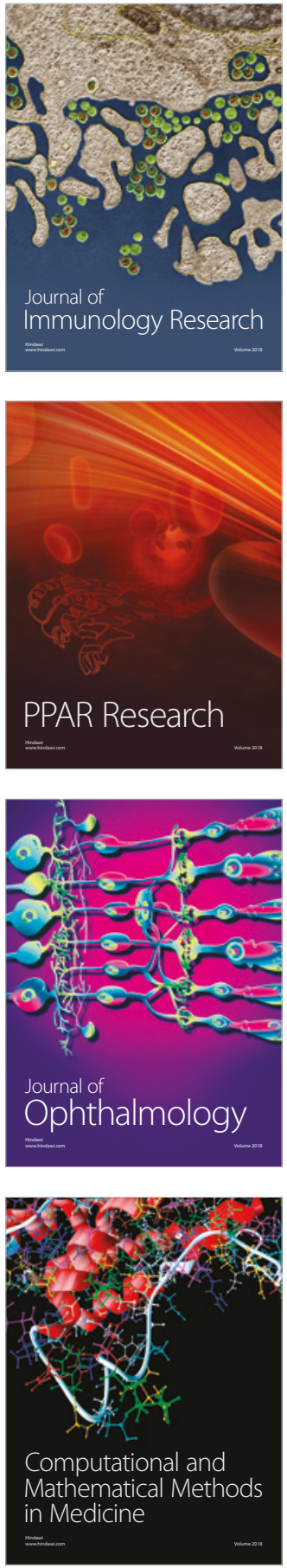

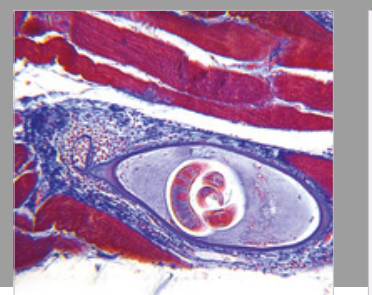

Gastroenterology Research and Practice

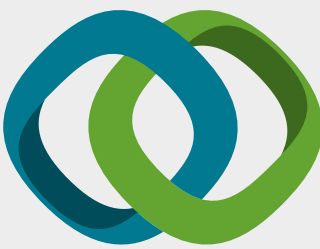

\section{Hindawi}

Submit your manuscripts at

www.hindawi.com
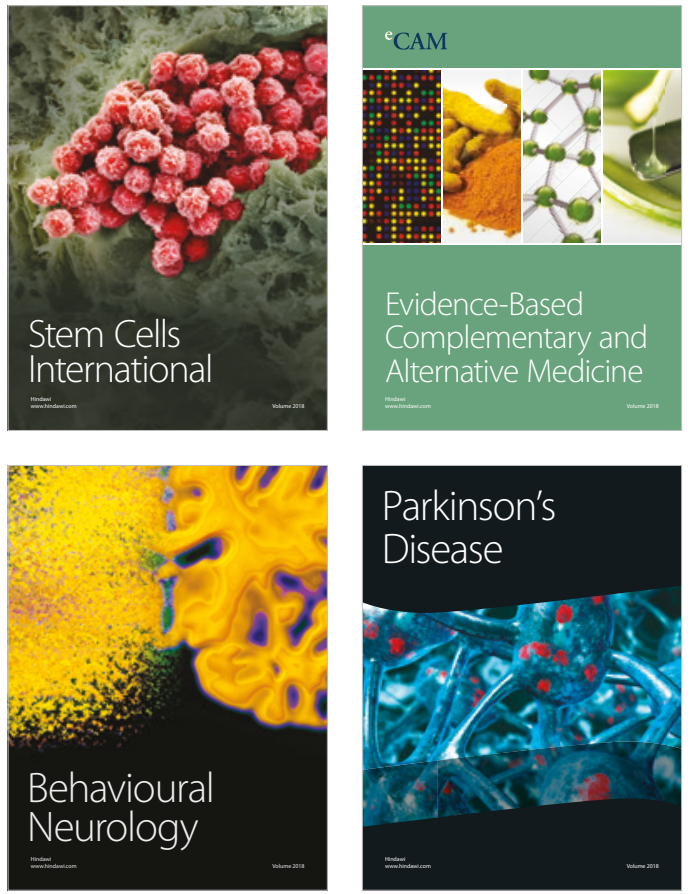

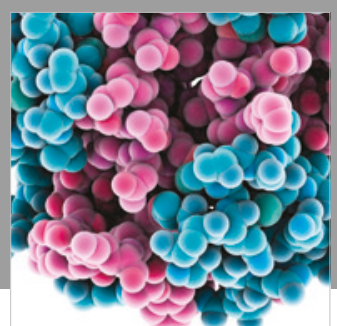

ournal of

Diabetes Research

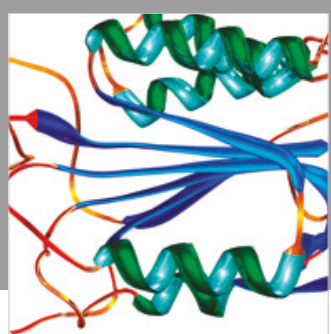

Disease Markers
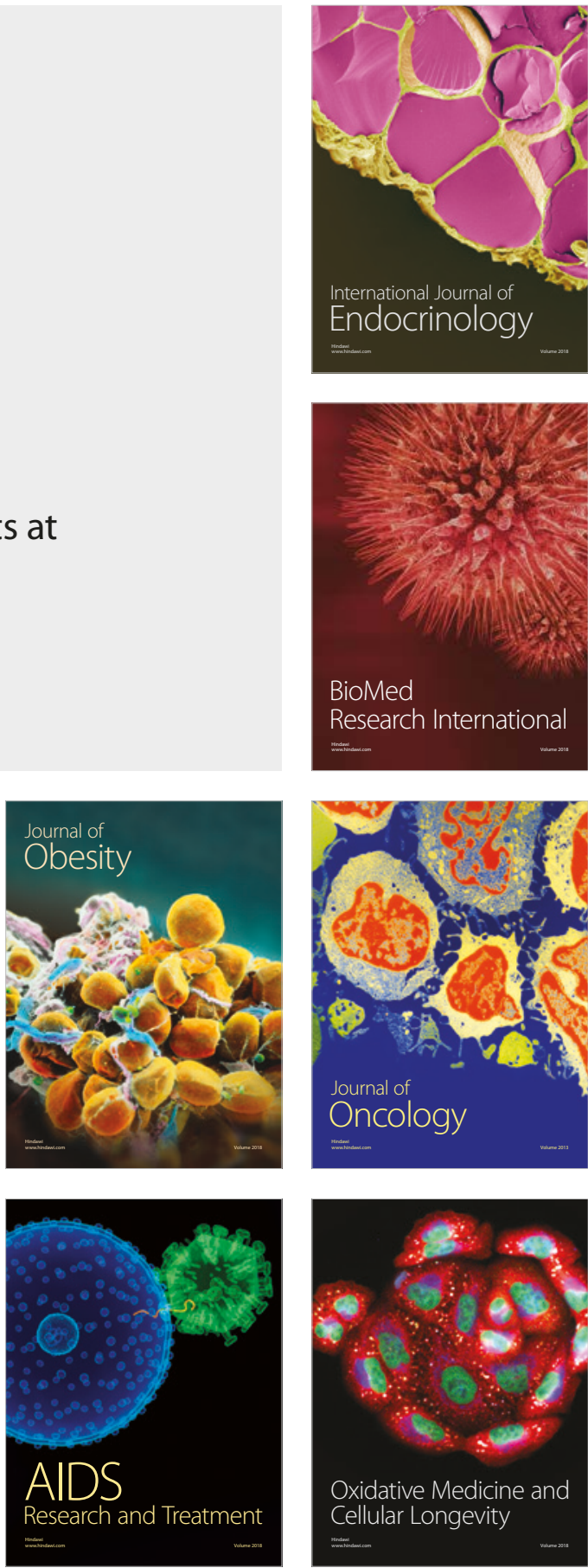